ANA PATRICIA CARNEIRO GONÇALVES BEZERRA COELHO

ESTUDO DA INFLUÊNCIA DO ENVELHECIMENTO E DA PERDA DOS ELEMENTOS DENTAIS NOS NÍVEIS TOTAIS DE IMUNOGLOBULINA SECRETÓRIA DO TIPO A NA SALIVA 



\section{Ana Patrícia Carneiro Gonçalves Bezerra Coelho}

Estudo da influência do envelhecimento e da perda dos elementos dentais nos níveis totais de imunoglobulina secretória do tipo A na saliva

Dissertação apresentada à Faculdade de Odontologia da Universidade de São Paulo, para obter o título de Mestre, pelo Programa de PósGraduação em Odontologia.

Área de Concentração: Prótese Dentária

Orientadora: Profa. Dra. Dalva C. Laganá

São Paulo 


\section{FOLHA DE APROVAÇÃO}

Bezerra-Coelho APCG. Estudo da influência do envelhecimento e da perda dos elementos dentais nos níveis totais de imunoglobulina secretória do tipo A na saliva [Dissertação de Mestrado]. São Paulo: Faculdade de Odontologia da USP; 2005.

São Paulo, /2005

\section{Banca Examinadora}

1) $\operatorname{Prof}(a) \cdot \operatorname{Dr}(a)$.

Titulação:

Julgamento: Assinatura:

2) $\operatorname{Prof}(a) \cdot \operatorname{Dr}(a)$.

Titulação:

Julgamento:

Assinatura:

3) $\operatorname{Prof}(a) . \operatorname{Dr}(a)$.

Titulação:

Julgamento:

Assinatura: 


\section{DEDICATÓRIA}

Às pessoas que mais amo:

meu avô, Humberto (eternas saudades),

que com amor, dedicação, trabalho e devoção foi um exemplo de vida pessoal e acadêmica. Pela força, mesmo na sua ausência.

meus pais, Gláucio e Magnólia, meus grandes amigos, pela dedicação, incentivo e companheirismo durante toda a minha vida. Por terem sido as primeiras pessoas a acreditar que eu era capaz de tantas conquistas.

meu marido, Luiz, a quem agradeço por todo carinho, paciência e por estar sempre ao meu lado.

meu querido filho, Gabriel, que tem me proporcionado uma gestação tranqüila possibilitando a conclusão deste trabalho, e que tem sido meu companheiro de todas as horas e razão de minha luta (é por você que tudo vale a pena). 
meus irmãos, Thereza e Gláucio,

meus melhores amigos, que, cada um ao seu jeito, estão sempre ao meu lado, e que contarão com meu carinho, amor e gratidão por toda a vida.

minha tia, Magda, pela sabedoria e pelo exemplo de que a conquista depende de nós mesmos.

minhas primas, Clara e Dulce, pela presença em todos os momentos de minha vida.

À minha família, tios e primas, que apesar de longe compartilham de minhas conquistas. 
À Profa. Dra. Dalva Cruz Laganá, minha eterna gratidão, pela sua amizade, confiança, exemplo de perseverança e pela oportunidade de ser sua orientada. 


\section{AGRADECIMENTOS}

A Faculdade de Odontologia da Universidade de São Paulo, na pessoa do Prof. Dr. Ney Soares de Araújo.

Ao Presidente da Comissão de Pós-Graduação da FOUSP Prof. Dr. João Humberto Antoniazzi.

Ao Prof. Dr. Carlos Gil, chefe do Departamento de Prótese Dentária da FOUSP.

Ao Prof. Dr. Gerson de Arruda Corrêa pelo apoio e carinho nos momentos mais difíceis e por acreditar em meu potencial.

Aos professores do Departamento de Prótese Dentária da Faculdade de Odontologia da Universidade de São Paulo, em especial Prof. Dr. Roberto N. Yamada, pela oportunidade, carinho e apoio científico, imprescindíveis na minha formação acadêmica.

Aos integrantes da ONG Envelhecer Sorrindo, de modo muito especial, a Profa. Dra. Maria Luiza A. Frigério pelo auxílio nesta pesquisa. 
As queridas Patrícia Palmeira, Gerlândia, Simone, Cristiane, Elaine, Mariana e, de modo muito especial, a Cris, pelo carinho, amizade, apoio, companheirismo e auxílio prestado tanto no âmbito profissional quanto pessoal.

Aos professores, funcionários e amigos do Laboratório de Imunologia de Mucosa do ICB III, pelo carinho com que me receberam.

Aos meus queridos colegas do Curso de Pós-Graduação em Prótese Dentária, pela amizade, afeto e convivência.

As secretárias do Departamento de Prótese Dentária da FOUSP, Coraci, Regina, Sandra e Valdinéia, pela atenção, carinho, paciência e dedicação com que atenderam todas as minhas necessidades acadêmicas e pessoais.

As bibliotecárias da FOUSP, especialmente a Glauci, pela pronta resposta a todas as nossas questões e pelas horas dedicadas com carinho a correção dos manuscritos.

Á Adriana, pelo carinho na análise e interpretação estatística.

Aos pacientes que participaram desta pesquisa e aos meus pacientes que, com muita paciência, contribuíram para a conclusão deste trabalho.

E a todos que direta ou indiretamente contribuíram para o desenvolvimento deste trabalho. 
Bezerra-Coelho APCG. Estudo da influência do envelhecimento e da perda dos elementos dentais nos níveis totais de imunoglobulina secretória do tipo A na saliva [Dissertação de Mestrado]. São Paulo: Faculdade de Odontologia da USP; 2005.

\section{RESUMO}

O objetivo desta pesquisa foi avaliar a influência do envelhecimento e da perda dos elementos dentais nos níveis totais de imunoglobulina secretória do tipo A (SIgA) na saliva. Foram selecionados 76 pacientes (entre 20 e 87 anos), os quais foram divididos em três grupos de acordo com sua faixa etária e condição bucal: adultos jovens com idades de 20 a 40 anos (Grupo lou Grupo controle); idosos com idade entre 65 e 78 anos, desdentados parciais, portadores de prótese total unimaxilar (Grupo II) e idosos com idade entre 65 e 87 anos, desdentados totais, portadores de prótese total bimaxilar (Grupo III). Os níveis totais de imunoglobulina secretória do tipo A na saliva foram determinados por meio da técnica de ensaio imunoenzimático em fase sólida ( ELISA Enzyme-linked Imunosorbent Assay). Após obtenção dos dados experimentais foi empregada a análise de variância de ANOVA com dois fatores (sexo e grupo) para verificar o efeito significante da interação destes fatores. Os níveis totais de imunoglobulina do tipo A secretória na saliva não apresentaram, em média, diferenças significantes entre os três grupos. Em relação ao fator gênero, ou sexo, em média, homens e mulheres apresentaram comportamentos de SIgA diferentes nos grupos. Para o grupo controle o nível total de SIgA dos homens foi maior que o das mulheres enquanto que para o grupo III o nível total de SIgA das mulheres foi maior que dos 
homens e para o grupo II não foi observada diferença significante dos níveis de SlgA entre homens e mulheres. Pela análise comparativa dos grupos I e III foi observada diferença significante no sexo feminino, o que não foi observado quando comparados os dois grupos experimentais (Grupos II e III). Os resultados desta pesquisa sugerem que não há influência direta dos fatores envelhecimento e perda dental sobre os níveis totais de imunoglobulina secretória do tipo A na saliva. Estes resultados mostraram a influência do gênero sobre os níveis de imunoglobulina secretória do tipo A. Entretanto, a influência do gênero não é bem conhecida e merece mais estudos.

Palavras-Chave: Imunologia de mucosa; Imunoglobulina A; Prótese Total; Envelhecimento; Perda dental 
Bezerra-Coelho, APCGB. Study of the influence of senescence and teeth loss on secretory immunoglobulin A levels. [Dissertação de Mestrado]. São Paulo: Faculdade de Odontologia da USP; 2005.

\section{ABSTRACT}

The aim of this study was to evaluate the influence of senescence and teeth loss on secretory immunoglobulin A (Slg A) levels in saliva. Seventy-six patients (20 to 87 years old) were selected and classified in three groups according to their age and oral dental state: young adults were aged 20-40 years (Group I or Control group); elderly subjects were aged 65-78 years and wore maxillary or mandibular denture (Group II); and edentulous old subjects were aged 65-87 years and wore maxillary and mandibular denture (Group III). The secretory immunoglobulin A levels were determined by the Enzyme-linked imunosorbent assay (ELISA method). All results were correlated using ANOVA statistical analysis with two factors (sex and group) to verify the significant effect of these factors. The secretory immunoglobulin A levels were not significant differences among the average values of the three groups. In gender relation, men and women showed the mean rate of SIgA levels different in the groups. The men SlgA levels of control group showed greater when compared to women levels. In Group III the women levels were greater when compared to men levels. And to Group II statistical analysis demonstrated no significant difference between the SlgA levels of men and women. The analysis showed significant differences in the women levels when compared to Groups I and III. No differences of levels were demonstrated when compared to Groups II and III. 
These results suggests that the senescence and teeth loss do not have a direct relationship to the secretory immunoglobulin A levels in whole saliva. The se results showed that there is influence of gender in the secretory immunoglobulin levels. However, the influence of gender is not well known and further studies are still necessary.

Keywords: Mucosal Immunology; Immunoglobulin A; Complete denture; Senescence; teeth loss 


\section{LISTA DE TABELAS}

Tabela 2.1 - Mudanças no sistema imune durante a senescência 49

Tabela 2.2 - Alterações funcionais celulares durante o envelhecimento. .64

Tabela 5.1 - Amostragem: idade, número de pacientes e condição bucal

Tabela 5.2 - Distribuição de pacientes segundo gênero e grupo. .78

Tabela 5.3 - Medidas descritivas de S $\lg$ A segundo grupo e sexo....... .78

Tabela 5.4 - Medidas descritivas de SIgA segundo grupo e sexo excluindo paciente com SIgA de 2220 .80 


\section{LISTA DE GRÁFICOS}

Gráfico 5.1 - Perfil médio de SIgA segundo grupo e sexo......

Gráfico 5.2 - Perfil médio de SIgA segundo grupo e sexo, excluindo paciente com SIgA $=2220$. 


\section{LISTA DE ABREVIATURAS E SIGLAS}

$\begin{array}{ll}\mu l & \text { microlitro } \\ \mu \mathrm{m} & \text { micrômetro } \\ \text { Abs } & \text { absorbância } \\ \text { ELISA } & \text { ensaio imunoenzimático em fase sólida } \\ \text { IgA } & \text { imunoglobulina A } \\ \text { OPD } & \text { ortofenileno diamina } \\ \text { PBS } & \text { salina tamponada com fosfato } \\ \text { rpm } & \text { rotações por minuto } \\ \text { SlgA } & \text { imunoglobulina A secretória }\end{array}$




\section{LISTA DE SÍMBOLOS}
$\alpha \quad$ alfa
$\beta \quad$ beta
$\gamma \quad$ gama
$\%$ por cento 


\section{SUMÁRIO}

1 p.

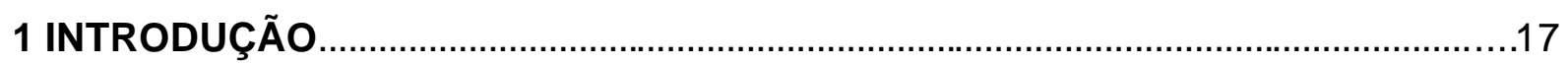

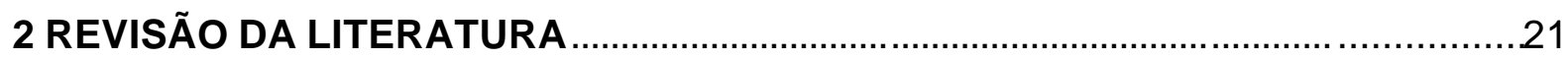

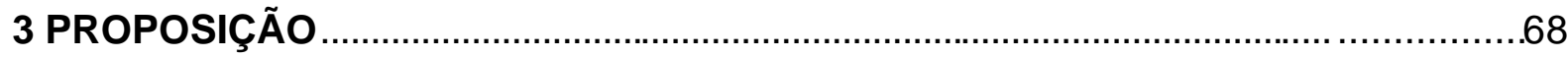

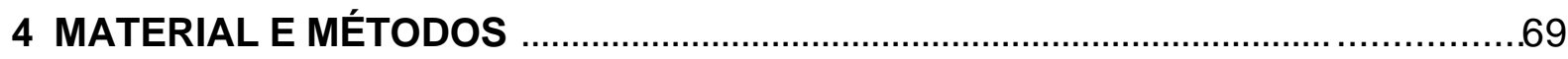

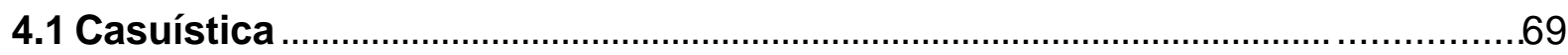

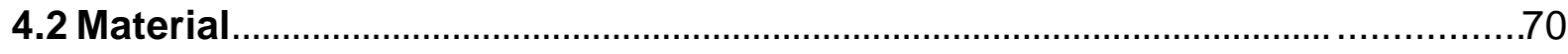

4.2.1 materiais e instrumental para a anamnese e exame clínico bucal ......................70

4.2.2 materiais para a coleta das amostras de saliva .................................................. 71

4.2.3 aparelho de armazenagem das amostras ............................................................

4.2.4 materiais e equipamentos utilizados para determinação dos níveis de imunoglobulina A secretória salivar através da técnica de ELISA ............................71

4.2 .5 outros materiais e equipamentos utilizados............................................................

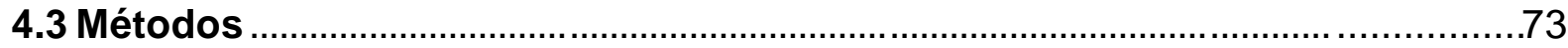

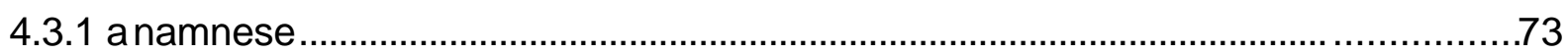

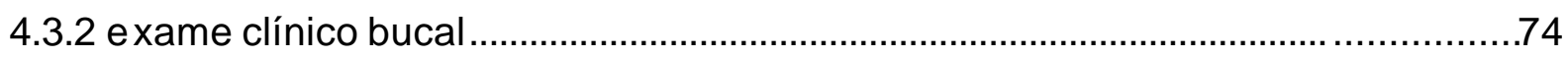

4.3.3 coleta das amostras de saliva para análise imunológica ......................................74

4.3.4 determinação dos níveis totais de Imunoglobulina A através da

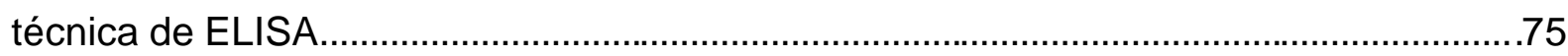

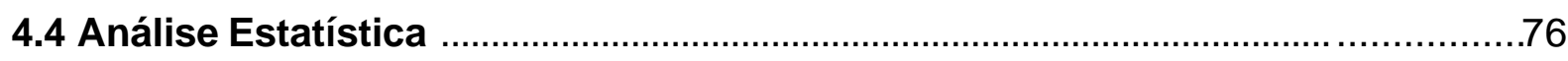

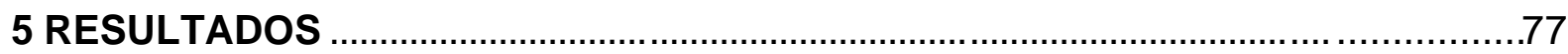

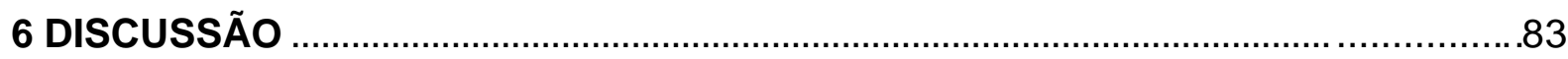

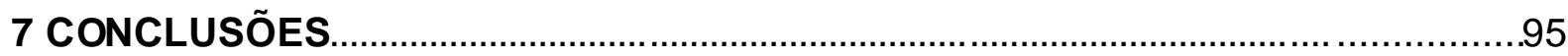

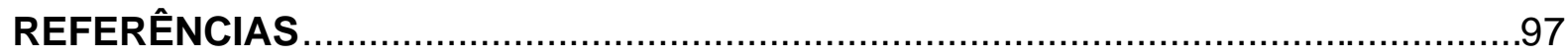

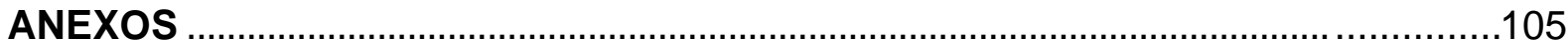




\section{INTRODUÇÃO}

O envelhecimento da população mundial está causando um grande impacto nas nações. Na Europa e América do Norte, esse fenômeno iniciou-se há quase cem anos, enquanto que em outras regiões, incluindo o Brasil, começou a partir da década de sessenta. No Brasil há 8.489 .958 idosos, o que corresponde a 5,85\% da população nacional segundo o censo demográfico do IBGE de 2000. Diante destes dados e do rápido crescimento desta parcela da população aumentou a procura pelos cuidados profissionais, o que justifica maior desenvolvimento de estudos voltados para o entendimento da senilidade, em diferentes áreas, entre elas a Odontologia.

O envelhecimento deve ser observado, cada vez mais, como um processo natural da existência do ser humano e não mais como o preâmbulo do fim desta existência. Esta etapa da vida, com a manutenção de todas as funções, não significa problema nem para o indivíduo nem para a sociedade; os problemas surgem quando as funções começam a se deteriorar.

O preparo para uma velhice saudável deve iniciar-se por volta dos 30 anos de idade, com medidas preventivas mantidas com constância por toda a vida. Essas têm como objetivo evitar dores nas articulações, assim como os efeitos negativos que acompanham o estresse diário e os riscos de problemas cardiovasculares (TONIOLO NETO, 1999). As diferenças que permeiam a juventude e a senilidade podem variar de 
acordo com as condições sócio-econômicas, de trabalho, convívio familiar, ambiente e as modificações que ocorrem no próprio organismo em decorrência do processo de envelhecimento.

Essas alterações, em primeira instância, levam a pensar sobre os aspectos físicos visíveis como o encanecimento dos cabelos e fâneros, o ressecamento da pele e o aparecimento das rugas (SOUZA-LEÃO, 1999). Além desses aspectos, relaciona-se ainda muito o processo de envelhecimento à condição dental do indivíduo, mais especificamente, à perda dos elementos dentais.

Diante da importância deste fator nos aspectos fisiológicos, psicológicos e sociais, essa perda influi sobre o indivíduo de forma marcante, podendo predispor às doenças geriátricas (MORIGUCHI, 1992). Da mesma forma que as alterações sistêmicas interferem na saúde bucal, esta também pode alterar a saúde geral do indivíduo. E neste aspecto cabe ao profissional alertar o paciente e incentivá-lo no cuidado com a saúde bucal.

No entanto, raramente é lembrado das modificações ocorridas nos órgãos internos, muito menos as ocorridas no sistema imune.

Estudando-se a senescência deve-se considerar que as modificações dos diferentes sistemas ocorrem de modo diverso. Isto fica muito claro quando são analisados alguns parâmetros fisiológicos como a velocidade de condução do impulso nos neurônios, a taxa de metabolismo basal, o rendimento cardíaco e a capacidade 
respiratória máxima. Algumas destas ações se tornam mais deficientes que outras. A função respiratória em indivíduos acima de 70 anos, está reduzida em $50 \%$ de sua capacidade operacional, enquanto que as outras variáveis analisadas estão afetadas no máximo em 30\% (DICE, 1993). Assim, torna-se muito difícil definir o estado de envelhecimento saudável, pois para isto há que se saber quais as modificações decorrentes do estado de senescência, suas conseqüências no indivíduo como um todo e os fatores que podem influenciar o estado de saúde da pessoa, para poder-se distinguir das alterações decorrentes de doenças existentes.

Mais especificamente, quando se consideram as funções do sistema imune, observa-se que um sinal do processo de envelhecimento é a diminuição da habilidade de montar uma resposta imune humoral. $\mathrm{O}$ aumento da susceptibilidade à doenças infecciosas, o aumento da incidência de câncer e outras desordens envolvendo a função imune dos idosos têm demonstrado um declínio da resposta imune deste grupo.

Como a maioria das doenças infecciosas envolve inicialmente a colonização e penetração das superfícies mucosas por microorganismos, então, o sistema imunológico de mucosas é de suma importância para promover a proteção necessária nesta etapa.

Em muitas espécies, incluindo o homem, as mucosas são protegidas pela imunoglobulina do tipo A. A IgA secretória está presente em várias secreções humanas como nas lágrimas, saliva, leite e secreções mucosas do trato intestinal e da porção superior do trato respiratório. 
Na saliva há a predominância da imunoglobulina A secretória dimérica ${ }^{1}(S-\lg A)$, mas pode-se detectar também a presença da sua forma monomérica, originária por difusão do soro. No entanto, os níveis de imunoglobulinas salivares não são constantes e acredita-se que o fator envelhecimento possa influenciá-los.

O sistema imune pode ser utilizado como um marcador de senescência considerando-se que ele está intimamente ligado ao estar saudável e, portanto, sua disfunção poderá ser correlacionada com morbidade e mortalidade (SOUZA-LEÃO, 1999).

Diante dessa observação verifica-se a importância da mensuração do nível total de IgA salivar, que proporciona a avaliação da integridade do sistema imune de mucosa humano e é útil para monitorar tanto agressões antigênicas quanto fisiológicas (GLEESON; CRIPPS; CLANCY, 1995), fato este que motivou a investigação deste trabalho.

\footnotetext{
${ }^{1} \mathrm{~A} \operatorname{Ig}$ A possui uma cadeia pesada com domínio C-terminal adicional (segmento da cauda) que permite à IgA interagir com uma molécula bivalente (ou polivalente), conhecida como cadeira J, com conseqüente formação de dímeros (ou trímeros ) de $\operatorname{IgA}$. A polimerização da IgA é importante pois a IgA polimerizada possui maior capacidade de se ligar a antígenos e aglutiná-los. Além disso, a IgA dimérica possui a capacidade de interagir com o componente secretor, uma proteína produzida pelas células epiteliais. Este componente atua como receptor de transporte para a IgA e torna-se parte integrante da molécula de IgA secretada.
} 


\section{REVISÃO DA LITERATURA}

Blazkovec, Orsin e Maginn (1973) realizaram um estudo sobre o dimorfismo sexual na resposta imune primária de hamsters sírios. Foram estudados e comparados os padrões de resposta imune primária de hamsters machos e fêmeas, adultos jovens, que receberam injeção de preparado com células vermelhas do sangue de ovelhas como antígeno. Foram observados os níveis de resposta utilizando os seguintes parâmetros: células formadoras de colônias presentes no baço, níveis de hemaglutinina e hemolisina e síntese de imunoglobulinas. Primeiramente analisaram os padrões de resposta nos animais adultos jovens (58-68 dias) e depois os efeitos da idade (400-550 dias), do ritmo circadiano e da gonadectomia pré e pós puberal. As fêmeas apresentaram uma produção maior de células formadoras de colônia que os machos. Não foram observadas diferenças significantes nas médias de hemaglutinina, hemolisina e média de anticorpos humorais (IgG e $\operatorname{lgM}$ ). Foram obtidos resultados similares quando comparados aos animais idosos. Estes resultados independeram do ritmo circadiano dos machos, e os efeitos da pré ou pós-puberal gonadectomia sobre a resposta imune primária sugeriram que a vantagem das fêmeas em termos de síntese de imunoglobulinas específicas depende primariamente da relativa ausência dos hormônios gonadais masculinos.

Storch e Bellagamba (1982) realizaram um trabalho de atualização sobre a prática da odontologia em pacientes idosos e seus problemas, afirmando que se deve afastar dos indivíduos maduros a idéia de que velhice é sinônimo de prótese completa. 
Constataram que, entre outros fatores, "há perda de reservas físicas e aumento da propensão ao trauma, à infecção e às doenças crônicas." Em relação às manifestações orais do envelhecimento observaram que os dentes se tornam frágeis e fraturam facilmente; há maior incidência de cáries radiculares; a mucosa oral perde a elasticidade e há uma menor quantidade de saliva devido à reduzida função das glândulas salivares e atrofia das células dos condutos. Portanto, concluem que os odontólogos devem ter sempre como objetivo promover e manter a saúde oral durante toda a vida através de diagnósticos adequados e tratamentos individualizados.

Smith, Ebersole e Taubman (1983) realizaram uma pesquisa sobre a resposta imune local e sistêmica em hamsters idosos. Foram mensurados e comparados níveis de imunoglobulina no soro e saliva em hamsters de 23 meses e 2 anos. Estas concentrações de imunoglobulina foram obtidas por meio do método de imunodifusão radial simples. A concentração de SlgA em hamsters idosos não foi estatisticamente significativa. Também o volume salivar foi maior, resultando em uma maior quantidade de SlgA por tempo. No soro, $\lg G$ e $\lg A$ apresentaram-se em maior concentração, enquanto que para IgM foi menor. Após imunização com glucosiltransferase de $S$ mutans, a concentração de SlgA foi menor em idosos, após a primeira e segunda imunizações, enquanto que $\lg G$, $\lg A$ e $\lg M$ séricas não apresentaram diferenças significantes em relação a idade, após a imunização. Estas concentrações foram analisadas por uma modificação do método de ensaio imunoenzimático em fase sólida (ELISA). 
Lappalainen, Yli-Urpo e Knuuttila (1985) observaram o efeito do uso de próteses removíveis com recobrimento de palato nas concentrações de proteínas, amilase e IgA da saliva total de homens idosos. Foram examinados 166 pacientes nascidos em 1925. Foram divididos em dois grupos: I (101 pacientes) - indivíduos que utilizavam próteses com recobrimento de palato e II (65 pacientes) - indivíduos dentados sem próteses. As amostras de saliva foram coletadas no período da tarde, entre 12:30 e 15:30 horas, sem estimulação. Após análises químicas observaram que quando a secreção salivar estava entre 2 e 2,9ml/5min a diferença da concentração de amilase entre os grupos era significativa, sendo maior para o grupo controle. Enquanto que com o fluxo maior que $1,9 \mathrm{ml} / 5 \mathrm{~min}$ a respectiva diferença na concentração de proteína é que era significativa. Em relação à concentração de $\lg A$ a presença da prótese reduz o fluxo salivar e aumenta a concentração desta imunoglobulina. Portanto, concluíram que o recobrimento de palato da prótese afeta as concentrações de proteína e de $\lg A$ especialmente quando o fluxo salivar é menor.

Madeira, Caetano e Minatti (1987) apresentaram a odontogeriatria com uma necessidade curricular e deram ênfase à necessidade de alerta dos profissionais de odontologia, dos poderes públicos e dos próprios idosos para a importância do papel que o sistema estomatognático desenvolve para o estado geral de sua saúde. As patologias buco-dentais isoladas ou associadas determinam a falência da capacidade mastigatória alterando assim o estado de saúde geral do indivíduo.

Kalache, Veras e Ramos (1987) afirmaram que o envelhecimento populacional é um fenômeno universal, atingindo tanto os países desenvolvidos quanto os em 
desenvolvimento. Os fatores responsáveis por este processo de envelhecimento são, principalmente, o declínio das taxas de fecundidade e das taxas de mortalidade. Entre 1960 e 2020 a expectativa média de vida ao nascimento, em países de terceiro mundo, terá aumentado em mais de 23 anos, atingindo os 68,9 anos. Nos países desenvolvidos, o aumento na expectativa de vida será comparativamente menor, passando de 69,8 anos, em 1960 para 77,2, em 2020. Este número para os países desenvolvidos é o esperado tendo em vista o limite biológico da espécie humana. 0 "relógio biológico" da espécie humana se situa em torno dos 85 anos. Portanto, apesar de muitos continuarem associando a velhice aos países mais desenvolvidos tanto da Europa quanto da América do Norte, a maioria dos idosos do mundo vive em países do terceiro mundo desde a década de cinqüenta.

Ramos, Veras e Kalache (1987) observaram no Brasil a passagem de uma situação de alta mortalidade e alta fecundidade para uma de baixa mortalidade e, gradualmente, baixa fecundidade; o que se traduz em uma elevação da expectativa de vida média da população e um aumento em termos absolutos e proporcionais do número de pessoas atingindo idades avançadas. No Brasil, enquanto a população como um todo terá um aumento de cinco vezes entre 1950 e 2025, no mesmo período o aumento da população idosa será da ordem de 15 vezes. Iniciamos este novo século com a população idosa crescendo proporcionalmente quase oito vezes mais que os jovens e quase duas vezes mais que a população em geral. Tal crescimento tornará o Brasil, no ano de 2025, o país com a sexta maior população de idosos do mundo em termos absolutos. 
Gronblad e Lindholm (1987) estudaram a concentração de imunoglobulinas salivares em pacientes predentados e edêntulos. Foram avaliadas concentrações de $\lg \mathrm{A}$, IgG e IgM da saliva total de pacientes predentados, adultos dentados e idosos edentados e concentração de IgG sérica em idosos dentados, por meio de um radioimunoensaio em fase sólida. A concentração de lgG na saliva de idosos edentados foi de $5,2 \mathrm{mg} / \mathrm{l}$, o que significa $20 \%$ da concentração em relação aos indivíduos idosos dentados. Isto os levou a concluir que esta concentração advém de outros sítios que não o do fluido crevicular que seria responsável pelos $80 \%$ restante. Os bebês apresentaram concentração de $\operatorname{lgG}$ salivar significativamente menor que os outros grupos $(1,7 \mathrm{mg} / \mathrm{l})$, o equivalente a $5,6 \%$ do valor do grupo de idosos dentados. Isto ocorreu, segundo os autores, devido a ausência do fluido gengival e ao estado imaturo e parcialmente desenvolvido do sistema imune. O nível de $\lg \mathrm{A}$ salivar nesta idade também foi baixo. Não houve diferença significante entre os valores de $\lg \mathrm{A}$ salivar de idosos edentados e adultos dentados. Já os idosos edentados tenderam a ter baixa concentração de $\operatorname{lgM}(2,0 \mathrm{mg} / \mathrm{l})$ e os bebês, alta concentração de lgM comparados com indivíduos dentados, o que os levou a concluir como sendo um mecanismo compensatório para a baixa concentração de $\lg \mathrm{A}$.

Aguirre et al. (1987) estudaram a concentração de $\lg A$ secretória e a-amilase na saliva parotídea estimulada em indivíduos de 23 a 84 anos. Os pacientes foram divididos, de acordo com a idade, em três grupos: I (23-39 anos); II (40-59 anos) e III (60-84 anos). A concentração de a-amilase foi obtida por meio de ensaio de imunodifusão radial simples, enquanto que a concentração de $\lg A$ secretória foi obtida por meio de análise imunoeletroforética. No entanto, não foram encontradas diferenças 
estatisticamente significativas nas concentrações de $\lg \mathrm{A}$ e a-amilase na saliva parotíd ea entre os grupos.

Smith, Taubman e Ebersole (1987) avaliaram a capacidade de resposta do sistema imune secretório durante toda a vida. Isto foi feito através de medições das concentrações de $\lg A$ e $\lg A 1$ em amostras de saliva de indivíduos com idades de 2 meses a 91 anos. Além disso, mensuraram a atividade da $\lg A$ específica para poliovírus e glicosiltransferase do $S$. mutans através do ensaio imunoenzimático em fase sólida (ELISA - Enzymelinked Imunosorbent Assay). Observaram que a saliva total de crianças de 2 a 5 meses continha menor concentração de $\lg A$ que a saliva proveniente da glândula parótida de qualquer grupo de adultos. Também uma proporção significativamente alta do $\lg A$ total era $\lg A 1$ nas crianças em comparação ao encontrado na saliva parotídea dos adultos. No entanto, quando os autores compararam o nível total de $\lg \mathrm{A}$ e $\lg \mathrm{A} 1$ da saliva dos adultos jovens e idosos (70-91 anos), não houve diferença. Quanto às imunoglobulinas específicas, verificaram que os níveis de $\lg \mathrm{A}$ para glicosiltransferase do $S$. mutans era insignificante na maioria das amostras de saliva das crianças com menos de 5 anos de idade, enquanto que $40 \%$ das crianças maiores de um anos apresentaram níveis detectáveis de IgA para poliovírus. Já no grupo mais idoso (70-91 anos) houve escassa distribuição e uniformemente baixos níveis de $\lg \mathrm{A}$ específica para ambos os antígenos. Concluíram que, como os níveis de $\lg A$ eram os mesmos para os adultos jovens e idosos, este baixo nível de $\lg$ A específico pode ser associado com mudanças no número ou função dos linfócitos T ou B ou células apresentadoras de antígeno, e/ou pode ser resultado dos menores níveis de exposições a estes antígenos. 
Ben-Aryech e Cohen (1988) realizaram um estudo da composição e fluxo salivares de pacientes diabéticos insulino-dependentes. Foram selecionados 35 pacientes portadores de diabetes mellitus e 31 pacientes controle. Os autores observaram uma diminuição do fluxo salivar total, uma maior concentração de glicose, de potássio e de proteínas, mas não observaram diferença significativa na concentração de sódio, de $\lg \mathrm{A}$ e na atividade da amilase nos pacientes diabéticos insulino-dependentes. Portanto, os autores concluíram que as glândulas salivares são afetadas pela diabetes mellitus insulino-dependente.

Ekelund (1989) realizou um estudo sobre o estado dental e a habilidade mastigatória de idosos institucionalizados. Foram examinados e entrevistados 480 pacientes de 24 instituições em diferentes partes da Finlândia. O autor dá ênfase à relação entre a habilidade mastigatória e a dificuldade dos idosos se alimentarem de certos alimentos devido a seu pobre estado dentário. Afirma também que, apesar da perda dentária não ser uma conseqüência fisiológica do envelhecimento, é amplamente aceito que uma arcada dentária completa em um paciente idoso é um fato raro e que, de 60 a $90 \%$ da população idosa tem sido freqüentemente descrita como edêntula. No entanto, cerca de 10 a $40 \%$ dos pacientes edentados não foram reabilitados. Este estado leva os pacientes a optarem por consumir alimentos menos consistentes tendendo à má nutrição.

Segundo Figueiredo, Yurgel e Lorandi (1990) os tecidos da cavidade bucal também sofrem alterações decorrentes do processo natural de envelhecimento, que não devem ser confundidas com manifestações patológicas. A mucosa do idoso pode 
apresentar, sob o ponto de vista clínico, aspecto de normalidade, no entanto, admite-se que intrinsecamente, ela seja menos resistente que a de um jovem pelas alterações celulares, metabólicas e pela redução da secreção das glândulas salivares, tornando-se mais atrófica. Com isso a elasticidade também diminui, o que torna esta mucosa mais suscetível à lesões.

Schuurs e Verheul (1990) realizaram uma revisão sobre os efeitos do gênero e dos hormônios sexuais na resposta imune. Afirmam que as fêmeas, em modelos animais e humanos, possuem respostas imunes elevadas e uma maior incidência de doenças autoimunes. Nesse estudo, os autores discutem as diferenças de resposta entre machos e fêmeas em humanos, em roedores e em pássaros; e o papel do gênero e dos hormônios sexuais nas doenças autoimunes em várias espécies. Concluem que o gênero e os hormônios sexuais apresentam um efeito sobre as respostas hetero e auto imunes, mas, que os mecanismos pelos quais isto ocorre ainda não estão claros e que similares de hormônios podem ser utilizados no tratamento da doença autoimune.

Mann et al.(1990) realizaram um estudo avaliando o estado clínico dentário e determinando vários aspectos comportamentais da população de idosos não institucionalizados. Os autores tiveram como objetivos avaliar a utilização dos serviços odontológicos por esta população e determinar as razões da não utilização por alguns. Observaram que, de sua amostra (87 pacientes), 56\% era edêntula e 19,5\% era parcialmente edentada. Observaram também que 42,4\% visitaram o dentista no último ano e que $37,6 \%$ não foram ao dentista nos últimos 5 anos. Destes últimos, $62,7 \%$ não 
apresentavam problemas, 9,8\% apresentavam problemas financeiros, 5,9\% se diziam ocupados e $3,9 \%$ com medo.

Streckfus, Welsh e Strahl (1991) realizaram um estudo sobre a influência do uso de medicação antihipertensiva, em uma população idosa negra, em relação a secreção parotídea de $\lg A$. Neste estudo os autores utilizaram um grupo controle com 15 idosos saudáveis normotensos e outro grupo com 19 idosos hipertensos que utiliza medicação antihipertensiva. Foram coletadas amostras de saliva proveniente da parótida para análise da quantidade de $\lg A$ (por imunodifusão radial), proteína total (por spectofotômetro) e eletrólitos. Como resultados, observaram diminuição de sódio $(p<0,01)$, diminuição do fluxo salivar $(p<0,23)$ e diminuição da secreção de $\lg A$ $(p<0,022)$ no grupo medicado. Além disso, este grupo apresentou uma maior incidência de cárie radicular.

Tenovuo (1992) realizou um estudo a cerca dos fatores de defesa oral dos idosos por meio do sistema imune. Afirma que a mais severa e prevalente mudança na defesa oral é a hiposalivação ou xerostomia, mas o envelhecimento não reduz o fluxo salivar total nem o parotídeo. Mas, as glândulas submandibulares e as menores produzem menos saliva em idosos, o que pode ser a razão para o sintoma de secura bucal, freqüentemente apresentado pelos pacientes, ainda que o fluxo estimulado esteja normal. Juntamente com estas mudanças no fluxo, a produção diária de muitos fatores de defesa mediados pela saliva diminui, mas, tem sido descrito que há prejuízo para a resposta de $\lg \mathrm{A}$ a antígenos externos, para atividade de opsonização salivar e para a função do linfócito $T$. Os fatores de defesa não relacionados com as 
imunoglobulinas agem com sua total capacidade durante toda a vida. Por fim, o autor conclui que idosos com fluxo salivar normal não representam grupo de risco para o desenvolvimento de patologias bucais.

Moriguchi (1992) observou os aspectos geriátricos do atendimento odontológico e salientou a importância do profissional (CD) conhecer as alterações biológicas do idoso e a influência negativa que a perda dos dentes e o uso da prótese causam à saúde. Entre as alterações biológicas bucais, a mais importante é a perda dental. Esta influi sobre a mastigação, digestão, gustação, pronúncia, aspecto estético e predispõe à doenças geriátricas. Por fim, o autor afirma que a perda dos elementos dentais, juntamente com a diminuição da atividade social provocam o envelhecimento cerebral, pois aumenta o fator de risco da aterosclerose cerebral.

Smith et al. (1992) avaliaram o efeito da idade na concentração de $\lg G, \lg A$ e $\lg \mathrm{M}$, no volume de saliva estimulada da região labial inferior e de saliva prove niente da parótida. Foram avaliados 264 pacientes com idades entre 17 e 76 anos. Os autores observaram que $70 \%$ dos indivíduos dos grupos mais velhos (61-70 e 71-76 anos) secretaram menos saliva da região labial que os do grupo mais novo (18-20 anos). 0 fluxo salivar parotídeo não apresentou alteração relacionada com a idade. Enquanto que a concentração de $\lg A$ da saliva da região labial inferior foi significativamente menor nos indivíduos de mais idade (média de 55,6+/- 1,3 anos). Mas IgG, IgM da saliva labial e parotídea, e IgA da saliva parotídea não apresentaram diferenças com a idade. Segundo os autores, estes dados sugerem que os potenciais fisiológicos e imunológicos da saliva labial diminuem com a idade. 
Arranz et al. (1992) observaram os efeitos da idade nas concentrações de SlgA e número de linfócitos intraepiteliais. Foram mensuradas concentrações de imunoglobulinas e isótipos específicos de anticorpos específicos para três antígenos da dieta (gliadina, ovoalbumina e beta lactoglobulina) no soro, saliva parotídea e secreção intestinal obtida pela lavagem gástrica de um grupo de indivíduos idosos saudáveis (mais de 70 anos) e de adultos jovens controles (25-50 anos). Além disso, foram contadas células da lâmina própria e células linfóides intraepiteliais em espécimes de biópsia do jejuno dos indivíduos idosos e adultos jovens. Nos idosos a concentração de $\lg A$ sérica foi maior e de $\lg M$ menor que nos jovens. A concentração das classes de $\lg M$ para as três proteínas da dieta também foram significativamente menores que nos jovens. Na saliva a concentração de $\lg \mathrm{A}$ foi maior nos idosos, portanto os autores observaram uma correlação positiva entre idade e concentração de $\lg A$ no grupo idoso e, as concentrações de $\lg G$ e $\lg M$ também foram maiores. A concentração de SlgA específica para as proteínas da dieta também foram maiores. No fluido gástrico não houve diferença na concentração total de imunoglobulinas ou nos valores de anticorpos específicos quando comparados os dois grupos. Os espécimes todos estavam histologicamente normais e nos idosos os linfócitos intraepiteliais apareceram em menor quantidade. Na lâmina própria, células contendo $\lg A$ estavam em maior quantidade. E na contagem de outras células da lâmina própria como células com IgM, com lgG, mastócitos e eosinófilos, não houve diferença entre os dois grupos. Portanto, conclui-se que há efeitos da idade sobre o sistema imune de mucosa.

Rosa, Rocha e Lopes (1993) observaram no jovem portador de diabetes mellitus insulino dependente a prevalência de cárie e das imunoglobulinas salivares e 
concluíram que este tem a mesma susceptibilidade à cárie dos outros indivíduos, mas que a maior prevalência de cárie pode ser atribuída à diminuição do fluxo salivar e não ao déficit de imunoglobulinas na saliva. Estes resultados foram obtidos através da imunodifusão radial simples em saliva estimulada. Por fim, concluíram que a diabetes juvenil não prejudicou a produção e o transporte das imunoglobulinas salivares, em particular, a $\lg \mathrm{A}$.

Migliare e Marcucci (1993) e Migliare (1990) realizaram a medição dos níveis de $\lg$ A secretória na saliva total não estimulada de indivíduos fumantes e não fumantes por imunodifusão radial simples. Mostraram que a imunodepressão tem sido apontada como causa na patogênese de doenças malignas o que os levou ao estudo, pois existe ação imunodepressora causada por produtos de combustão do tabaco. A análise estatística revelou um déficit quantitativo da IgA secretória em indivíduos que fumam acentuadamente. O consumo médio de 40 cigarros por dia gera um efeito imunodepressor sobre a produção de $\lg$ A secretória nas glândulas salivares. Portanto, o tabagismo, em consumo elevado, pode produzir um efeito imunodepressor sobre os níveis salivares de $\lg A$ secretória.

Dice (1993) realizou um estudo sobre os mecanismos celulares e moleculares do envelhecimento e observou que a função respiratória, em indivíduos acima de 70 anos, está reduzida em $50 \%$ de sua capacidade operacional, enquanto que as outras variáveis analisadas estão afetadas no máximo em $30 \%$. 
Lopez-Jornet e Bermejo-Fenoll (1994) observaram a relação da idade com a secreção salivar total. O estudo foi realizado com 1493 pacientes entre 5 e 88 anos. Os autores observaram que o hábito de fumar não apresentou influência sobre a secreção salivar, mas esta diminuiu com a idade. No entanto esta diminuição deve ser considerada com cautela pois não apresentou relação direta com a idade, mas sim para cada grupo idoso estudado.

Olsen et al. (1994) analisaram a indução da proliferação de timócitos imaturos após castração de rato macho normal. Foram comparados animais castrados com 8-10 semanas de idade com animais normais. Os timócitos foram analisados após 4-120 dias da castração em relação à fase do ciclo celular em que se encontravam. Dos timócitos obtidos das glândulas intactas cerca de $11+/-1 \%$ estavam em fases ativas do ciclo. A porcentagem de timócitos no ciclo aumentou para $22,5+/-1,9 \%$ na semana seguinte à castração. Com 8-10 dias após a castração o peso do timo aumentou consideravelmente ao dobro dos controles. Nestes timos aumentados apenas 9,9+/$0,8 \%$ das células estavam em ciclo, o que não foi significantemente diferente dos timos controle. Isto sugere que o papel dos andrógenos intratimicamente é afetar a geração do repertório de células T maduras.

Tappuni e Challacombe (1994) compararam a concentração de IgA salivar e suas subclasses em crianças predentadas, dentadas e adultos. Compararam também os níveis em crianças com alimentação no seio materno e as amamentadas com mamadeira. Amostras de saliva to tal foram coletadas de 44 crianças predentadas (média de 4 meses de idade); 29 crianças dentadas (média de um ano e meio de idade) 
e 28 adultos (média de 19,5 anos de idade). Foi utilizado o método de ELISA. Nas crianças predentadas as concentrações de $\lg A, \lg A 1$ e $\lg A 2$ foram menores que no grupo dentado, no entanto, só houve diferença estatisticamente significante na concentração de $\lg A 2$. As concentrações nos adultos foram significativamente maiores que nas crianças. E não foram encontradas diferenças estatisticamente significantes entre as crianças alimentadas no seio materno e as alimentadas com mamadeira.

Streckfus et al. (1994) examinaram a composição e o fluxo salivar parotídeo em indivíduos idosos negros diabéticos e edentados em comparação a indivíduos da mesma faixa etária, mesma raça, mesma condição bucal e não diabéticos. Os participantes tinham no mínimo 65 anos e foram divididos em quatro grupos. O grupo $\mathrm{A}$ (15 participantes) era o controle, composto por indivíduos não diabéticos. O grupo B (14 participantes) composto por indivíduos insulino dependentes. O grupo C (12 participantes) composto por indivíduos tratados com medicação oral. E o grupo D (5 participantes) composto por indivíduos tratados apenas com regimes alimentares para o controle da axa de glicose. Todos os pacientes diabéticos apresentavam valores de glicose no soro menores que $250 \mathrm{mg} / \mathrm{dl}$. Os autores avaliaram fluxo salivar, concentração de $\operatorname{lgA}$, de eletrólitos $(\mathrm{Na}+, \mathrm{Cl}-, \mathrm{K}+, \mathrm{Ca}++)$ e concentração total de proteínas. Como resultados não observaram diferenças significantes em relação ao fluxo salivar e concentrações de IgA e eletrólitos. No entanto, os indivíduos diabéticos apresentaram menor concentração total de proteínas.

Segundo Hayflick (1994), para os gerontologistas, a idade cromológica tem apenas sentido legal e/ou social, uma vez que as idades biológica e cronológica não 
estão diretamente correlacionadas. O tempo, por si só, não produz efeitos biológicos. Os eventos ocorrem no tempo, mas não por que este passa. As mudanças relacionadas com a idade ocorrem nas diferentes partes do corpo em tempos diferentes. Segundo este mesmo autor, não há como mensurar a idade biológica dos seres humanos e da maior parte dos animais, pois os eventos que se seguem ao nascimento acontecem em momentos e ritmos diferentes em cada um de nós. Saber a idade biológica pode ser mais informativo que saber a cronológica, mas não se tem como mensurar isto. Isto não é devido à falta de pesquisas, pois, os gerontologistas têm tentado diversos tipos de medidas biológicas, como por exemplo, a medida da cor do cabelo, comprimento da orelha, função cardíaca e capacidade de realizar exercícios físicos. No entanto, nenhuma destas constituiu um método infalível de medida da idade biológica, por uma importante razão: é muito individual a variabilidade nos marcadores em potencial do envelhecimento. Por isso se utilizam certidões de nascimento e outros documentos para se estabelecer a idade do indivíduo. Quanto à imunidade do indíviduo idoso, este possui uma menor eficiência em montar uma resposta imune quando requerida, e um declínio na habilidade do sistema de produzir anticorpos para substâncias estranhas é unido com uma grande chance deste mesmo sistema produzir anticorpos para proteínas próprias. Segundo o autor, muitos gerontologistas acreditam que o aumento da incidência do câncer com a idade é resultado de uma menor capacidade do sistema imune de detectar e destruir células cancerígenas que nos jovens. Para o autor, o fluxo salivar e seus componentes são estáveis durante o envelhecimento. 
Challacombe, Percival e Marsh (1995) observaram os efeitos da idade nos níveis de imunoglobulinas salivares e séricas além da taxa de secreção das imunoglobulinas salivares em uma população adulta saudável. 116 indivíduos foram divididos em grupos de acordo com a faixa etária (20-39; 40-59; 60-79; acima de 80 anos). Foram coletados saliva total, a estimulada proveniente da parótida e o soro e as imunoglobulinas tanto salivares como séricas foram quantificadas por ensaio imunoenzimático em fase sólida (ELISA - Enzyme-linked Imunosorbent Assay). Os autores observaram que os níveis de imunoglobulinas séricas tipo $\mathrm{G}(\lg G)$ e tipo $M(\lg M)$ eram significativamente reduzidos no grupo mais idoso, mas não foi observada redução significante no nível de IgA com a idade. Os níveis de $\lg A$ e $\lg G$ na saliva como um todo aumentou significativamente no grupo mais idoso, mas não foram detectadas alterações nos níveis de IgM. Não foram encontradas alterações em nenhum nível de imunoglobulina relacionadas com a idade na saliva proveniente da parótida. No entanto, reduções significantes foram observadas nas taxas de secreção de $\lg A$ e $\lg M$, mas não em $\lg G$, no grupo mais idoso, em saliva total. Os resultados obtidos demonstraram que um declínio nas taxas de secreção de imunoglobulina na saliva e um declínio nas concentrações de imunoglobulina circulante com o aumento da idade devem contribuir para o aumento da susceptibilidade dos idosos a doenças infecciosas.

Viselli et al. (1995) realizaram um estudo sobre as alterações que a castração de ratos machos normais produz nas funções do sistema imune periférico. As fêmeas apresenta ram aumento das respostas mediadas por células e anticorpos diante de uma estimulação antigênica, no entanto, ainda não é conhecida a base fisiológica para este dimorfismo sexual da resposta imune. Neste estudo foram examinadas as 
conseqüências de uma deficiência prolongada de andrógenos sobre o sistema imune periférico. Os animais foram castrados com 6 semanas de vida e a comparação com animais normais foi realizada após 3-4 meses da castração. Foram analisados caracterização fenotípica das subpopulações de timócitos e linfócitos; produção in vitro de interleucina 2, interleucina 4 e interferon gama; e níveis totais de imunoglobulinas ( $\lg G, \lg A$ e $\lg M)$ e anticorpos autoreativos. Os animais castrados apresentaram hipertrofia tímica e ampliação do baço, principalmente devido a expansão da população de células B. Estes baços continham relativamente menos células $T$ maduras que os controles; e quando analisadas as culturas destas células haviam maiores níveis de interleucina 2 e interferon gama. Quanto à síntese de imunoglobulinas, esta não foi maior nos animais castrados, mas as culturas de células do baço dos animais castrados apresentou maiores índices de produção de dois autoanticorpos (anti-lgG ou fator reumatóide e anti-tiroglobulina). Os autores concluíram que uma privação de andrógenos resulta em um relativo decréscimo no número de células maduras periféricas do tipo T, em um aumento da produção de Interleucina 2 e interferon gama , expansão do compartimento de células periféricas do tipo B e um aumento da capacidade de produção de autoanticorpos.

Franceschi et al. (1995) realizaram um estudo a cerca da imunologia de indivíduos centenários e observaram que vários parâmetros imunológicos são conservados, sugerindo que uma complexa remodelação do sistema imunológico ocorre com a idade antes de uma deteriorização. A escolha destes indivíduos foi para avaliar-se as últimas décadas da vida no intuito de se entender a importância do envelhecimento com sucesso e apreciar a imunosenescência fisiológica. Constataram 
ser de fundamental importância a escolha cuidadosa dos indivíduos a serem estudados levando em consideração que, em indivíduos saudáveis muitos parâmetros imunológicos que eram tidos como deterioráveis com a ação da idade não sofrem alteração como um todo.

Weksler (1995) realizou um estudo sobre a imunosenescência observando se esta seria uma deficiência ou uma disregulação do sistema. A involução tímica é conhecida a mais de 100 anos. O timo é um órgão central de desenvolvimento imune. Isso sugere que a imunosenescência seja um estado de deficiência imune. O fato de que muitos pacientes idosos desenvolvem infecções mais freqüentemente e de forma mais severa em comparação a indivíduos jovens e que poucos dos idosos são protegidos por vacinas que protegem adultos jovens suportam esta hipótese. $\mathrm{Na}$ literatura, com o passar dos anos, observa-se que alterações imunes, associadas com o envelhecimento, são mais ligadas a disregulação imune que a deficiência do sistema. Os autores observaram que o sistema imune desvia a atenção de antígenos estranhos para auto antígenos e que o nível de auto anticorpos aumenta com a idade. Além disso, que a rotina de imunização é menos eficaz em idosos e que as células $T$ diminuem muito com a idade. A disregulação da imunidade celular associada com a idade tem sido menos estudada que a imunidade humoral. Concluem que uma forma de melhorar a função adaptativa do sistema imune nos idosos deve ser re-regulando os elementos que tem lançado o sistema imune fora de controle para se acrescentar mais vitalidade biológica ao sistema. 
Gleeson, Cripps e Clancy (1995) realizaram uma revisão sobre os modificadores do sistema imunológico mucoso. Os autores afirmam que os mais significativos modificadores da imunidade mucosa humana são eventos que ocorrem no período de maturação neonatal e, posteriormente na vida, a interação entre o sistema imune e o sistema neuroendócrino. Fixaram-se especificamente no uso da saliva como um modelo para monitorar a maturação imunológica, imunocompetência e respostas imunológicas específicas, apresentando tanto vantagens quanto desvantagens das medidas na saliva. Primeiramente a saliva é um modelo de grande importância pois reflete adequadamente a condição do sistema imune mucoso e é obtida de maneira não invasiva o que facilita a repetição do experimento quando necessário. Observaram que a medida de IgA proporciona mensuração da integridade do sistema imunológico mucoso humano e é útil para monitorar respostas antigênicas como fisiológicas.

Marcus et al. (1996) realizaram um estudo sobre edentulismo e uso de próteses nos idosos da Nova Inglaterra. Coletaram informações sobre saúde bucal de uma parcela representativa de idosos. O exame bucal e a entrevista foram conduzidos por dentistas e entrevistadores calibrados, respectivamente. De 1156 participantes, 424 $(36,7 \%)$ eram edentados. A taxa de edentados foi similar para mulheres e homens e foi negativamente relacionada com nível de educação e renda. Dos indivíduos edentados $89,9 \%$ tem próteses bimaxilares. Muitas destas próteses (82,2\%) eram usadas durante o dia, e mais de um terço usava uma ou as duas durante a noite. Este alto índice de edentulismo foi preocupante pois, segundo os autores, o edentulismo pode afetar substancialmente a saúde geral e oral, bem como a qualidade de vida. Além de ter 
efeitos sobre o aspecto emocional e psicológico. O importante foi que a perda dos dentes não foi observada como sendo uma conseqüência da idade.

Miloro e McCormick (1996) realizaram um estudo sobre a seqüência normal de reparo cicatricial e observaram que esta é mantida nos idosos. Porém, foram observadas alterações dependentes da idade na seqüência de eventos deste processo. Ocorreu uma diminuição na resposta inflamatória e proliferativa com um atraso na angiogênese, epitelização e remodelamento. E houve uma diminuição na migração de fibroblastos e na síntese de colágeno.

Souza e Tamaki (1996) realizaram estudo xerca das implicações do uso da prótese total na geriatria e apresentaram a importância da manutenção do vínculo das alterações anatômicas, fisiológicas e fisionômicas com os aspectos psicológicos dos idosos. Estes fatores podem levar os indivíduos à não aceitação das próteses, apesar destas cumprirem com seus requisitos estéticos, funcionais, fonéticos e de conforto. Também dão ênfase ao colapso que ocorre no sistema estomatognático com a perda dos elementos dentais, o que deve ser suavizado com a instalação da prótese total. No entanto, como ocorre uma diminuição da capacidade de adaptação neuromuscular, é muito importante a correta anamnese e exame clínico antes da determinação do diagnóstico e prognóstico da prótese em questão.

Padilha e Souza (1997) realizaram um estudo no qual compararam o nível de edentulismo e cárie entre dois grupos de idosos do Brasil e da Inglaterra. Foram examinados 189 pacientes sendo 87 na Inglaterra e 102 no Brasil. Observaram que a 
média de idade dos brasileiros era de 73,6 anos e dos ingleses de 82 anos. Os ingleses apresentaram maior porcentagem de edentulismo $66,7 \%$ contra $43,1 \%$ nos brasileiros. A média dos dentes cariados foi de $39,9 \%$ nos brasileiros contra $22,6 \%$ nos ingleses. Os autores enfatizaram a importância da saúde bucal na manutenção do equilíbrio sistêmico devido a conhecida relação entre alterações bucais e sistêmicas, uma podendo predispor à outra. O número e qualidade dos dentes têm sido os mais freqüentes indicadores de saúde bucal utilizados pela epidemiologia

Vaz et al. (1997) realizaram um estudo acerca da imaturidade, envelhecimento e tolerância oral. Afirmaram que a tolerância oral é um fenômeno comum e diário, facilmente induzido em animais adultos imunocompetentes e mais difícil de ser conseguida em animais senis. Que após o período neonatal a susceptibilidade à indução da tolerância oral também diminui e isto pode ser restaurado com a transferência de células de jovens hospedeiros. Estes achados enfatizam que a atividade imunológica é uma contínua epigênese e que se extende por toda a vida do indivíduo, desde as fases mais precoces da ontogênese.

Frare et al. (1997) realizaram um estudo acerca dos problemas bucais que acometem pacientes da terceira idade. Este estudo foi realizado através de questionário domiciliar para obtenção de dados sobre a saúde bucal de indivíduos acima de 65 anos. Os autores observaram que $64,6 \%$ dos pacientes eram desdentados totais e apenas $73,4 \%$ utilizavam próteses. Foram observadas também alterações como: candidíase, periodontite severa e hiperplasia de palato causada por próteses com câmara de sucção. Por fim, os autores enfatizaram o papel do profissional no sentido 
de orientar e mostrar a importância dos dentes dos jovens, para que no futuro estes sejam idosos saudáveis.

Percival, Marsh e Challacombe (1997) realizaram um estudo sobre as mudanças, relacionadas à idade, nos anticorpos salivares da microbiota oral e intestinal. Os autores foram motivados pelo fato da prevalência das infecções mucosas aumentar com a idade sugerindo disfunção nas superfícies mucosas. Foram examinadas alterações de secreção e concentração de anticorpos secretórios da saliva total e da proveniente da parótida em uma população adulta saudável. 116 indivíduos foram divididos em grupos de acordo com a idade (20-39; 40-59; 60-79; acima de 80 anos). $\lg A$, IgG e IgM da saliva específicas para S. mutans, A. viscosus e E. coli foram quantificados por ensaio imunoenzimático em fase sólida (ELISA - Enzyme-linked Imunosorbent Assay). Os autores verificaram que $\lg$ e $\lg M$ salivares apresentaram um declínio com o passar da idade enquanto que os níveis de $\lg A$ aumentaram.

Padilha et al. (1998a) observaram que tem-se dado grande importância ao relacionamento da saúde bucal com a manutenção da saúde geral dos indivíduos bem como com a qualidade de vida durante o envelhecimento. O cirurgião dentista deve estar atento aos conceitos de envelhecimento saudável e com qualidade de vida, o que leva este profissional a uma maior busca por conhecimentos e alternativas de tratamento do paciente geriátrico. O mais importante é desesteriotipar a doença odontológica como sendo um processo inexorável e inevitável do envelhecimento. Priorizar a vida e a qualidade desta em qualquer indivíduo, seja lá que idade ele tenha. Os autores ressaltaram que o estado bucal do paciente idoso sofre influência de uma 
série de fatores que tornam este paciente susceptível à diversas patologias, não somente no órgão dentário, mas, também, nas diversas estruturas que compõem o sistema estomatognático. Atualmente, sabe-se que é possível manter boa saúde bucal até uma idade avançada e que a dentição não se perde em razão do processo de envelhecimento. Contudo os idosos continuam apresentando um alto risco de sofrer doenças bucais como a cárie, a doença periodontal e o câncer bucal. Além disso, alterações no fluxo salivar também são observadas, não como conseqüência do envelhecimento, mas como efeito colateral de determinadas medicações utilizadas por estes pacientes.

MacEntee, Glick e Stolar (1998) realizaram um estudo acerca da relação entre idade, gênero, próteses e alterações mucosas orais. Foram selecionados 255 pacientes. Os indivíduos foram entrevistados e examinados. Aproximadamente metade deles apresentou uma desordem mucosa. Houve uma significante associação entre lesões, uso de próteses e tabaco. Mas, a estomatite, a hiperplasia causada por próteses e a queilite angular foram associadas com o sexo masculino e com o uso de próteses defeituosas. Portanto, os autores concluíram que nem a idade e nem o uso de próteses inadequadas isoladamente predispõem às lesões, mas que, somados aos outros achados acima citados, aumentaram a ocorrência destas em portadores de próteses e indivíduos do sexo masculino.

Maupomé e Macentee (1998) avaliaram o uso de próteses em idosos independentes do Canadá, relacionando ao estado econômico, rede e suporte social destes. Observaram que a maioria dos usuários de dentaduras tinha renda alta ou 
suficiente para suprir suas necessidades. Verificaram que a presença de espaços anteriores não reabilitados por próteses estava relacionada a indivíduos menos dispostos ou capazes de sair de seus lares. Concluíram que o uso de próteses removíveis e espaços anteriores não tiveram relação com classe, rede ou suporte social.

Padilha et al. (1998) apresentou a necessidade da incorporação da odontogeriatria nos currículos de graduação e pós-graduação em odontologia o mais rápido possível devido ao aumento da população idosa no mundo e conseqüentemente a necessidade de estudos e cuidados especiais com estes pacientes. Estes cuidados, de modo especial na saúde bucal, têm o intuito de preservar os elementos dentais o máximo possível. A saúde bucal é vista pelos autores como um dos sustentáculos da qualidade de vida almejada pelos pacientes idosos durante o envelhecimento. Deixa claro que as universidades não devem "perder tempo" e sim, instituir a disciplina de odontogeriatria o quanto antes.

Werner et al. (1998) discutem o efeito do envelhecimento nos tecidos bucais e no atendimento odontológico ao idoso. Afirmam que a estimativa é de que em 2020 tenhamos $9 \%$ de pessoas acima de 65 anos. Com este aumento, cresce também a expectativa da manutenção dos elementos dentais. Mais importante se apresenta o conceito de qualidade de vida e, a saúde bucal apresenta uma grande influência sobre esta qualidade. Concluíram que ocorre uma diminuição na produção de saliva devido a perda de 20 a 30\% do componente acinar das glândulas salivares, mas, que ainda tem sido difícil demonstrar as mudanças na composição salivar. 
McArthur (1998) observou o efeito do envelhecimento sobre as células imunocompetentes e inflamatórias. Historicamente o aumento da ocorrência de infecções sérias como o câncer tem sido associado a indivíduos muito jovens ou muito idosos. Estas doenças ocorrem teoricamente por causa de uma diminuição nos mecanismos de defesa imune. Fatores ambientais e a diversidade genética da população são fatores pelo menos parcialmente responsáveis pela variabilidade de dados obtidos em relação a munosenescência em humanos. Centenários saudáveis podem ser considerados como tendo uma combinação genética, ambiental e de estilo de vida que permitiu chegar ao máximo de tempo de vida. $O$ fato de terem evitado doenças infecciosas fatais sugere que eles têm um sistema imune funcionando adequadamente, o que pode evitar muitos dos efeitos do envelhecimento. O autor deixa claro a necessidade de escolha de indivíduos saudáveis, sem doenças crônicas, retirando assim a influência destas sobre os resultados. Isto para separar efeitos fisiológicos da idade dos efeitos da doença, permitindo se estabelecer a biologia da imunosenescência. Com uma grande porcentagem de indivíduos vivendo mais, eles também vão reter mais dentes. Infecções orais indicam uma anormalidade sistêmica em um ou mais componentes das respostas imune e inflamatória de proteção. O aumento da ocorrência de infecções sérias e neoplasias em idosos tem sido usada como indicador de uma resposta imune adequada durante a idade avançada. Entretanto, até recentemente, não se encontrou uma relação causal direta entre alterações da idade na função imune com doenças infecciosas sérias ou neoplasias. A perda ou diminuição na função de um ou mais componentes do sistema imune durante o envelhecimento pode resultar em não imunidade, imunidade comprometida ou inapropriada. A involução tímica é a mudança mais óbvia relacionada com a idade que ocorre no sistema imune. 
As maiores mudanças no sistema associadas com a idade entre humanos são nos linfócitos $\mathrm{T}$. O número real de células $\mathrm{T}$ no sangue periférico diminui nos idosos. $\mathrm{O}$ número de células $B$ no sangue periférico também diminui com a idade, a quantidade de imunoglobulinas no soro pode ou não ser maior com a idade e as respostas de anticorpo são menores tanto para antígenos dependentes de células T quanto para os independentes, sugerindo que as células B como as T sofrem uma alteração associada à idade. Todas as superfícies mucosas, assim como o trato gastrointestinal, são susceptíveis à doenças infecciosas e inflamatórias. Existe dúvida de que a idade pode afetar a imunidade de mucosa, mais especificamente a resposta de $\lg A$. Senescência na imunidade de mucosa pode ser caracterizada por alterações de quantidade e qualidade. Imunogerontologistas estão investigando formas de diminuir, parar e/ou reverter os efeitos da idade no sistema imune. Terapias para restaurar o sistema são cogitadas. Como: 1. uso de anti oxidantes suplementares o que aumenta o número de células TCD4+ e proliferação de linfócitos no sangue periférico; 2. suplementos de zinco pois o zinco mantém o sistema nervoso, neuroendócrino e imune, restaura a morfologia tímica e função parcial das células imunológicas periféricas. Os centenários têm no sangue periférico menor número de linfócitos TCD3+, mais células T ativadas, menor número de células $\mathrm{B}$ e maior número de natural killers e células $\mathrm{T}$ que funcionam como natural killers.Número de eritrócitos, plaquetas e granulócitos são similares aos indivíduos jovens. Portanto, o autor concluiu que a resposta imune é afetada pelo envelhecimento.

McGrath e Bedi (1999) estudaram a importância da saúde bucal na qualidade de vida de pacientes idosos. Esta pesquisa foi realizada através de um questionário sobre 
a percepção de cada um acerca da relação entre saúde bucal e qualidade de vida. Foram analisados 154 indivíduos. Os autores observaram que $72 \%$ perceberam a saúde bucal como um fator importante para sua qualidade de vida e diferentes variáveis (física, psicológica e social). O mais freqüente foi o impacto sobre a função de comer (29\%) e, dos sintomas, o mais importante foi o conforto (14\%). Portanto, os idosos perceberam a saúde bucal como sendo importante na qualidade de vida de várias formas.

Toniolo Neto (1999) deixa claro que nunca é cedo demais para se preparar para a terceira idade. Que a grande arma em busca de uma velhice saudável é a prevenção, tendo-se como intuito não deixar a doença se instalar. Portanto, que a única coisa que ajuda a ter uma velhice saudável é uma juventude saudável e por isso os jovens procuram cada vez mais os geriatras preocupados em envelhecer com saúde.

Saliba et al. (1999) realizaram um estudo para conhecer, através de um questionário, as expectativas dos indivíduos da $3^{\circ}$ idade em relação aos serviços odontológicos prestados. Observaram que muitos apresentam necessidade de receber tratamento, mas, a falta de conhecimento e motivação quanto às medidas preventivas agrava o estado de saúde bucal desta população. Verificaram ainda, que a promoção da saúde bucal tem papel essencial impedind o repercussões negativas sobre o estado psicológico e de saúde geral do indivíduo.

Manetta, Brunetti e Montenegro (1999) analisaram a perspectiva da odontologia geriátrica através de uma rica revisão de literatura. E deixam claro a necessidade de um 
maior diálogo entre o profissional e o idoso para diminuir a ausência de dentes nesta população e para dar ênfase à necessidade da manutenção da saúde bucal. Também concluíram, que a população de idosos deverá crescer cerca de $250 \%$ nos próximos 25 anos enquanto que a parcela da população de indivíduos de 0 a 14 anos terá um decréscimo de cerca de $2 \%$. Por fim, os autores observaram a necessidade de uma maior interação entre a Medicina e a Odontologia para se trocar informações criando bases e diretrizes mais específicas para o tratamento dos idosos.

Naspitz et al. (1999) estudou os anticorpos anti - S mutans na saliva de crianças com diferentes graus de cárie para avaliar a relação entre o sistema imune secretório e as cáries. Utilizou um grupo sem cáries (grupo I), um com 1 ou 2 superfícies com cárie (grupo II) e outro com cárie rampante (grupo III). Para a análise imunológica foram utilizados os métodos de ELISA e Western blotting. Foi encontrado menor número de S mutans no grupo I em relação ao II e ao III. A concentração de imunoglobulina A secretória, IgA específica anti $S$ mutans, $\lg M$ e $\lg G$ não apresentaram diferenças estatisticamente significativas. Anticorpos para banda $185 \mathrm{kDa}$ foram encontrados nas salivas de indivíduos adultos e só uma criança do grupo III apresentou esta banda, o que sugere uma imaturidade imunológica das demais crianças. As propriedades da $\lg A$ são inibição da aderência bacteriana, produção de ácidos, neutralização de toxinas e prevenção de absorção de antígenos nas superfícies orais. A banda $185 \mathrm{kDa}$ representa a proteína responsável pela aderência inicial à hidroxiapatita. 
Souza-Leão (1999) relaciona as principais alterações do sistema imune frente a senescência e propõe o emprego deste sistema como biomarcador deste processo. Entre as alterações, a autora cita o remodelamento do sistema imune com a expansão de determinadas subpopulações de linfócitos T em detrimento de outras; o aumento de certos clones de linfócitos $\mathrm{T} \mathrm{CD8}^{+}$de memória que foram selecionados ao longo da vida; a expansão das células $\mathrm{T} \mathrm{CD} 8^{+}$e $\mathrm{T} \mathrm{CD} 4^{+}$de memória enquanto que as células $\mathrm{T}$ $\mathrm{CD} 8^{+}$e T CD4 ${ }^{+}$virgens praticamente desaparecem com o processo de envelhecimento; e a restrição da senescência à interface do sistema imune com o meio externo, isto é, para novos antígenos.

Madeira e Madeira (2000) apresentaram a complexidade do atendimento ao paciente geriátrico. Dão ênfase à acomodação do paciente às alterações que vão comprometendo o seu estado bucal e alertam o profissional que deve deixar bem claro que o envelhecimento não significa contrair e aceitar doenças. A saúde bucal é altamente responsável pela saúde geral do indivíduo.

Yung (2000) realizou um estudo acerca das mudanças na função imune com a idade. O envelhecimento é associado com um conjunto de mudanças no sistema imune, denominado de imunosenescência. Este conjunto é ilustrado pela tabela abaixo. 
Tabela 2.1 - Mudanças no sistema imune durante a senescência

\begin{tabular}{|c|c|}
\hline $\begin{array}{l}\text { Compartimento } \\
\text { Imune }\end{array}$ & Mudanças \\
\hline $\begin{array}{l}\text { Hematopoiese } \\
\text { Timo }\end{array}$ & $\begin{array}{l}\text { Prejuízo da proliferação das células progenitoras ao estresse } \\
\text { Involução tímica } \\
\text { Redução da produção hormonal pelo timo }\end{array}$ \\
\hline Células T & $\begin{array}{l}\text { Aumento da proporção entre células de memória e nativas } \\
\text { Redução da resposta proliferativa } \\
\text { Prejuízo da produção de IL2 } \\
\text { Prejuízo na função citotóxica }\end{array}$ \\
\hline Células B & $\begin{array}{l}\text { Prejuízo nas respostas humorais } \\
\text { Aumento na produção de } \operatorname{lgA} \text { e } \lg G \\
\text { Diminuição da produção de } \lg M \text { e } \lg D \\
\text { Aumento dos níveis de autoanticorpos }\end{array}$ \\
\hline Células NK & $\begin{array}{l}\text { Aumento do número no sangue periférico } \\
\text { Pouca ou Nenhuma mudança com a idade }\end{array}$ \\
\hline Células acessórias & $\begin{array}{l}\text { Diminuição no número de células de Langerhans } \\
\text { Diminuição da função das células acessórias do linfonodo }\end{array}$ \\
\hline Citocinas & $\begin{array}{l}\text { Aumento ou Nenhuma mudança na produção de IL6 e IL4 } \\
\text { Diminuição ou Nenhuma mudança na produção de IL2, IL10, } \\
\text { IL12, e interferon } \gamma\end{array}$ \\
\hline
\end{tabular}

Há um grande grau de variabilidade nas respostas imunes dos indivíduos de todas as idades e esta variabilidade aumenta com o envelhecimento. Como um todo, o envelhecimento é ligado a um declínio na habilidade do corpo do hospedeiro em se defender de patógenos estranhos e carcinógenos com associação a uma grande 
morbidade e mortalidade nos idosos de doenças infecciosas e câncer. E observa-se também uma menor incidência de doenças autoimunes nos idosos. É claro que respostas imunes protetoras são diminuídas no idoso e os mecanismos precisos, através desta deficiência imune, são pobremente estudados. Dentre os muitos fatores que contribuem para a imunosenescência, as mudanças na imunidade das células $T$ têm sido estudadas em grande detalhe. Estudos em humanos e animais sugerem que os defeitos ocorrem nas funções efetoras e indutoras das células T. Muitos estudos têm mostrado que o envelhecimento é associado a uma perda na habilidade de produzir anticorpos contra novos e já conhecidos antígenos. Não é claro que o envelhecimento está associado a um declínio na função primária da célula B. Muitos dos defeitos intrínsecos de células B podem ser explicados pelo efeito das células T envelhecidas sobre o desenvolvimento e função das células B. O envelhecimento é associado a elevados títulos de auto anticorpos. As mudanças relacionadas com a idade nos níveis de imunoglobulinas são modestas. Indivíduos idosos têm sido reportados como perdendo a habilidade de gerar anticorpos das classes IgA e IgG. Cabe destacar que, os níveis séricos de $\lg M$ e $\lg \mathrm{D}$ diminuem modestamente com a idade enquanto que os níveis de IgA secretória e sérica podem aumentar. Em resumo, o envelhecimento é associado com uma diminuição na função imune em humanos e animais. Os defeitos primários parecem residir no compartimento de células $T$. Entendendo os mecanismos que se encontram por baixo do declínio geral das funções imunes com a idade, podemos aumentar nossa habilidade para prevenir e tratar doenças associadas à idade. O desenvolvimento de um biomarcador de imunosenescência pode eventualmente ajudar clínicos a identificar subpopulações de idosos que têm risco de infecções, malignidades e possibilidade de desenvolver doenças auto imunes. 
Shinkai et al. (2000) avaliaram o perfil profissional dos alunos do curso sobre envelhecimento e saúde do idoso da Escola Nacional de Saúde Pública (ENSP) da Fundação Oswaldo Cruz (RJ). Entre as 21 profissões de nível superior representadas, as de maior freqüência foram Medicina, Psicologia e Serviço Social, ficando a Odontologia em $10^{\circ}$ posição, o que deixa claro a necessidade de interdisciplinaridade na formação do cirurgião dentista para atenção integral à saúde do idoso. Isto também mostra o pouco interesse dos cirurgiões dentistas no aprimoramento e aperfeiçoamento da gerontologia e geriatria mesmo trabalhando em instituições de assistência a idosos. Portanto, há necessidade da inserção da Odontologia na equipe de atenção à saúde do idoso através da incorporação do conceito de saúde integral na prática odontológica; a capacitação gerontológica no ensino, na pesquisa e na prestação de serviço e a divulgação da amplitude de atuação odontológica e de suas inter relações com as outras áreas profissionais.

Padilha et al. (2000) observaram o reparo da mucosa da língua de camundongos jovens e velhos (de 2 e 17 meses de vida). Foram produzidas feridas experimentais em 70 camundongos. Os autores procuraram diferenças histológicas no processo de cicatrização tendo como critérios para a análise: falha epitelial; infiltrado inflamatório; zona de fibrose; concavidade superficial e descontinuidade das papilas filiformes. Observaram diferenças individuais e na velocidade de ocorrência de infiltrado inflamatório e fibrose. No entanto, concluíram que o reparo ocorre de maneira similar em animais jovens e velhos. 
Koga et al. (2000) realizaram uma comparação entre as respostas imunes mucosas e sistêmicas de ratos velhos e adultos jovens. Ambos os grupos foram imunizados com três doses orais de $1 \mathrm{mg}$ de OVA e $10 \mu \mathrm{g}$ de toxina colérica. O rato idoso apresentou maior nível de IgM no soro que o rato adulto. Já IgG como IgA foram comparáveis para os grupos. Enquanto que em extratos fecais ocorreu nível mais alto de IgG nos idosos enquanto que os níveis de $\lg M$ e $\lg A$ não apresentaram diferença entre os grupos. Por fim, os autores observaram que alterações relacionadas à idade ocorreram precocemente no sistema imune de mucosa em relação ao sistema imune como um todo.

Breitbart e Stollar (2000) realizaram um estudo sobre a idade e o sistema imune humano. A manutenção do sistema imune regulado e vigoroso tem um importante papel para se ter uma vida longa e com saúde; a perda da função imune provavelmente sublinha o fato de que doenças infecciosas são as maiores causas de doenças e morte em idosos. O sistema imune sofre muitas mudanças no processo de envelhecimento que são refletidas em menores respostas de células $T$ a antígenos lembrados, menor formação de anticorpos em resposta a imunização e maior formação de autoanticorpos. Geralmente as mudanças são mais pronunciadas em células $T$ que nas funções das células B. Por muito tempo estas respostas alteradas foram tidas como sendo reflexo de um estado de imunodeficiência. Mas, atualmente, isso é visto como uma disfunção ou remodelação do sistema imune com a idade. No entanto, estes fatos podem ocorrer por alterações concomitantes e não devido ao envelhecimento, como doenças e má nutrição. Uma das manifestações mais consistentes do declínio do sistema imune é a menor resposta à imunização. Indivíduos idosos têm dificuldades em montar uma 
resposta protetora para vacinas de proteínas, vírus ou bactérias como a toxina tetânica, influenza e salmonella. O modo como estas respostas humorais reduzidas se relacionam com a morbidade e mortalidade da população idosa ainda precisa ser estudado. O aumento da freqüência de autoanticorpos tem várias hipóteses de causa. Uma delas é baseada na função do timo. Uma involução tímica assimétrica pode causar um desequilíbrio clonal com aumento em autoantígenos específicos indutores de células $\mathrm{T}$ relativo ao número de autoantígenos específicos reguladores de células $\mathrm{T}$. Este desequilíbrio pode estar relacionado a um progressivo aumento no número de folículos de células B presentes no timo. A imitação molecular por agentes infecciosos também pode ser gatilho para formação de autoanticorpos. As medidas do número total de linfócitos circulantes em indivíduos idosos apresentam diferentes resultados. No entanto, alterações em subpopulações de células T e função em indivíduos idosos têm sido consideradas mais consistentes que nos números totais. As menores respostas de células T podem levar a uma menor ativação de células B. Alterações nas populações de células $T$ e funções podem prover a base para entendimento tanto da diminuição de respostas celulares quanto da disregulação das respostas de células B. Portanto, ocorre uma diminuição da resposta de célula T a vários sinais, diminuição de respostas de anticorpos a antígenos em vacinas protéicas, virais e bacterianas e aumento da freqüência de formação de autoanticorpos não patogênicos. Existem muitas variações em se considerando a relação entre o sistema imune e a idade cronológica. Diante disso o autor afirma que a seleção do grupo de estudo é importante na pesquisa de envelhecimento e imunidade em humanos para excluir a possibilidade de interferência de outros fatores como conseqüências de patologias crônicas. 
Slavkin (2000) realizou um estudo acerca da maturidade e saúde bucal e observouque há uma grande associação entre envelhecimento e perda dental, uso de próteses e falta de necessidade de cuidados odontológicos adequados. Uma pobre saúde bucal pode aumentar o risco de doenças sistêmicas e condições destas, ou pode resultar de doenças sistêmicas. Uma pobre saúde bucal aumenta o risco de desenvolver infecção do trato respiratório, pneumonia e outras infecções sistêmicas pela aspiração das bactérias orais. Além disso, muitas doenças sistêmicas e condições como a imunodeficiência e deficiência de vitaminas são manifestadas na boca. Isto mostra a grande importância do diagnóstico oral. Os idosos produzem tanta saliva quanto o jovem o que faz com que a boca seca não seja uma característica da idade. Educação em saúde, promoção e prevenção de doenças são importantes para o século 21.

Castilhos (2001) identificou, através de métodos quantitativos e qualitativos, a importância de dentes e próteses para três grupos distintos de idosos, através de uma entrevista aberta associada a exames clínicos. Neste estudo o autor avaliou um grupo de idosos independentes, um grupo de idosos asilados em instituição filantrópica e um grupo institucionalizado em uma instituição particular. Com relação às características clínicas, o percentual de edentulismo foi elevado nos grupos asilados e foi observado que a cárie continua sendo um problema significativo na condição bucal dos idosos dos três grupos. Já o uso de próteses apresentou diferenças marcantes entre os grupos, em relação ao tipo e a quantidade. E, por fim, os idosos colocam que a alimentação, mastigação, digestão, seleção de alimentos, prazer de comer, aparência, aspectos psicológicos, aspectos psicossociais, comunicação, sorrir, sexualidade, higiene oral, 
saúde geral e qualidade de vida são influenciados pela presença e/ou ausência de dentes e próteses.

Harrod, Martin e Russell (2001) avaliaram a manutenção da memória do sistema imunológico de mucosa de animais idosos, ratos com 2 anos de idade. Os animais foram imunizados intragastricamente aos três meses de idade com proteína Ag VII do S. mutans acoplada a subunidade $B$ da toxina colérica e foi realizado o ensaio imunoenzimático em fase sólida (ELISA - Enzyme-linked Imunosorbent Assay) no soro, saliva e lavado vaginal dos animais. Os autores compararam animais imunizados com os controle, não imunizados. Os animais responderam de forma semelhante após a terceira dose. Concluíram que os ratos mantiveram a habilidade de montar respostas imunes aos agentes mucosos e que a memória a estes persistiu por toda vida.

Fujihashi et al. (2001) realizaram uma revisão sobre a imunidade de mucosa, IgA e tolerância oral. A indução de imunidade de mucosa por imunização oral com antígeno protéico apenas, é difícil. São necessários coadjuvantes mucosos potentes, vetores e outros sistemas especiais. A toxina colérica tem se mostrado uma efetiva adjuvante no desenvolvimento de vacinas mucosas e quando ministrada com vacina induz tanto resposta mucosa quanto sistêmica. O desenvolvimento de vacinas mucosas efetivas para idosos é também uma importante questão, entretanto, poucas informações são avaliadas. Quando se avaliou o uso da toxina colérica como coadjuvante em vacinas mucosas foi evidente uma disregulação imune prematura no rato idoso no sistema imune de mucosa. Para observar bem a natureza das respostas imunes de mucosa que ocorrem nos idosos recentemente, tem-se comparado as respostas de idosos e jovens 
adultos ratos semanalmente com três doses orais de $1 \mathrm{mg}$ de ovalbumina com $10 \mu \mathrm{g}$ de toxina colérica como adjuvante. Os estudos prévios têm mostrado que a imunização mucosa com antígenos protéicos coadministrados com toxina colérica (CT) arranca citocinas, especialmente IL4 e respostas mediadas pelo sistema imune de mucosa e respostas sistêmicas para antígeno protéico e a toxina. O estudo mostra que a disregulação ocorre no sistema imune de mucosa aos 12-14 meses de idade, enquanto a imunidade sistêmica continua igual, ou seja, normal. Mas, ratos com mais de 1-2 anos mostraram níveis reduzidos de respostas antígeno-específicas mucosas e/ou sistêmicas. Tem crescido o interesse pelos estudos de imunidade de mucosa, o que contribui para o melhor entendimento dos mecanismos celular e molecular para defesa de doenças infecciosas.

Kiyono et al. (2001) realizaram um estudo sobre o sistema imune de mucosa para defe sa especializada contra inflamação e alergia. O sistema imune é o elemento essencial para indução e manutenção de uma resposta imune apropriada. Ele consiste de sítios indutores e efetores onde os antígenos são recebidos, processados e apresentados às células imunocompetentes onde a produção de $\lg \mathrm{A}$ ocorre. A doença óssea inflamatória é crônica , a inflamação se limita a ossos largos e uma hipótese para patogênese desta doença é uma resposta imune de mucosa não controlada para um ou mais constituintes normais do intestino. $E$ as respostas alérgicas intestinais também tem relação com uma resposta anormal do sistema imune a várias proteínas da dieta ou modificadas por antígenos bacterianos intestinais. 
Schenck et al. (2001a) realizaram um estudo sobre imunidade inata e adquirida, citocinas e fatores genéticos em relação ao sistema imune de mucosa. Afirmaram que as respostas de imunidade adquirida podem ser divididas em sistêmicas ( $\lg G$ ) e mucosa (SIgA). E que para as respostas mucosas antígeno específicas o sistema imune mucoso comum deve ser ativado.

Schenck et al. (2001b) realizaram um estudo sobre Doenças mucosas mediadas imunologicamente. Os autores afirmam que a primeira estratégia anti-parasitas em relação à defesa mucosa é interferir na aderência parasita e a imune exclusão. Os microorganismos são atrapalhados em seu esforço para aderir às superfícies mucosas e encontrar apoios e nichos. Uma falha do sistema imune de mucosa em eliminar a bactéria com infecção crônica pode ter como conseqüência um dano tecidual.

Verthelyi (2001) realizou uma revisão sobre os hormônios sexuais como imunorreguladores na saúde e na doença. A atuação dos hormônios sexuais sobre o sistema imune resulta em um dimorfismo sexual onde as fêmeas apresentam maiores níveis de imunoglobulina e montam respostas mais vigorosas após imunização ou infecção que os machos. A grande resposta imune das fêmeas fica clara também em sua maior susceptibilidade às doenças autoimunes. Decifrar o mecanismo pelo qual os hormônios sexuais regulam o sistema imune é importante devido ao grande número de pessoas que estão utilizando hormônios sexuais como contraceptivos orais, em terapias de reposição ou suplementos alimentares. Em ratos, as fêmeas apresentam maiores níveis de imunoglobulinas séricas e produzem mais anticorpos para uma variedade de antígenos que os machos. Também tem menor incidência de tumores e rejeitam 
enxertos mais rapidamente. O efeito "protetor" dos andrógenos aparece em estudos nos quais a orquidectomia dos machos resulta em morte prematura e, em contraste, a administração in vivo de estrógeno acelera a progressão de doenças e morte. Nos humanos esta supremacia feminina aparece também em relação aos níveis de imunoglobulinas e à resposta imune a antígenos e se evidenciam após a menarca e diminuem após a menopausa. Portanto, os hormônios sexuais influenciam o desenvolvimento, maturação, ativação e morte das células imunes. No entanto, eles sozinhos não são responsáveis pelo dimorfismo sexual apresentado pelo sistema imune ou pelo desenvolvimento de doenças autoimunes.

Proctor e Carpenter (2001) estudaram a secreção estimulada de IgA salivar humana. Observaram que a secreção de $\lg A$, como de outras proteínas salivares, altera com o reflexo estimulatório. Foi coletada saliva proveniente da glândula parótida por estimulação em indivíduos de 22 a 40 anos de idade. A concentração de $\lg A$ foi avaliada pelo teste de ELISA e para observação do padrão de $\lg A$ foi utilizado a técnica de Western blotting que mostrou que formas de alto peso molecular de $\lg A$ contendo componente secretório predominaram em todas as amostras. Concluíram que o estímulo aumenta secreção de $\lg A$ pois leva a um estímulo da transcitose de $\lg A$ na célula epitelial.

Chiappelli et al. (2002) realizou um estudo sobre as necessidades dentais do idoso do século 21. Os problemas dentais associados com o envelhecimento incluem má higiene, dificuldade de controle e retenção de próteses e xerostomia. Esta última é comumente associada ao efeito de medicamentos e, tem como conseqüências: as 
cáries radiculares, a perda dental e a difícil mastigação. $78 \%$ dos idosos relatam não precisar ir ao dentista principalmente quando eles já são desdentados. Observou uma grande quantidade de ácido ascórbico no plasma de indivíduos com elementos dentais, observando que esse está relacionado ao número de dentes presentes. O número e a disposição dos dentes têm relação direta com o que os idosos comem. Idosos que consomem menos elementos energéticos têm declínio na vigilância mediada imunologicamente da mucosa dura e mole.

Su et al. (2002) realizaram uma revisão da clínica odontológica, em especial a odontogeriatria e ressaltaram a importância de manter a saúde bucal pela vida toda para conservar as funções. Juntamente com a necessidade do conhecimento da condição sistêmica do idoso para poder tratá-lo de modo a não influir de forma maléfica em sua condição.

Jansson, Lavstedt e Frithiof (2002) observaram a relação entre pobre saúde bucal e taxa de mortalidade (risco). Alguns sintomas de doenças ou causas de morte têm relação com a saúde bucal, especialmente doenças cardiovasculares. Foram registradas taxa e causa de mortalidade durante o período de 1971-1996. Na saúde bucal foram analisados número de dentes perdidos, lesões apicais, lesões de cárie e perda óssea. Os autores concluíram que há relação e que a pobre saúde bucal é um fator de risco de mortalidade.

Streckfus e Biigler (2002) observaram a importância da saliva como um fluido diagnóstico. Principalmente a habilidade de medir e monitorar os componentes da 
saliva e compará-los com os do soro auxilia nos estudos de marcadores imunológicos. Segundo os autores, a análise da saliva tem duas razões: primeiramente identificar indivíduos com doença e depois, seguir progresso de pacientes em tratamento. Como exemplo, a saliva analisada através de técnica de ligação enzimática observada com fluorescência em combinação com Western blot é superior ao soro e urina em relação a sensibilidade e especificidade para o HIV.

Nieuw Amerongen e Veerman (2002) analisaram a saliva como um defensor da cavidade oral. Afirmaram que a saliva mantém a saúde oral em condições normais. As imunoglobulinas da saliva têm grande importância no mecanismo de proteção específica. A IgA secretória é produzida por células B de todas as glândulas salivares e tem como ação antimicrobiana reação imune específica.

Chandra (2002) realizou um estudo acerca da nutrição em relação ao sistema imune do nascimento até a velhice. Observou que uma menor quantidade de proteína é associada com um significante prejuízo da imunidade celular, da função fagocítica, do sistema complemento, da concentração de $\lg A$ secretória e da produção de citocinas. Também a deficiência de alguns nutrientes resulta em alteração da resposta imune, como o zinco, selênio, cobre, vitamina "A", "C", "B6", "E”, ácido fólico e ferro. Indivíduos com baixo peso ao nascer têm um prolongado prejuízo da imunidade celular que pode ser parcialmente restaurada, provindo estes, de quantidades extras de zinco na dieta. Nos idosos o prejuízo imune pode ser diminuído com uma modesta quantidade de combinação destes nutrientes. A disfunção imunológica no idoso também se deve à prevalência de uma quantidade aumentada de autoanticorpos. A involução tímica reduz 
IgA sérica e não há dados sobre a resposta da IgA secretória nos idosos. Várias pesquisas têm mostrado a relação entre o estado nutricional e a incidência de infecção nos idosos. O que um suplemento de micro nutrientes melhora é a resposta imune do indivíduo e diminui a incidência de infecção respiratória e o uso de antibióticos.

Sequeira e Brunetti (2002) demonstraram a necessidade de políticas de saúde pública adequadas e atendimento especializado ao idoso. Ressaltaram que grupos multidisciplinares ligados à faculdades de Medicina já estão percebendo a importância da manutenção da saúde bucal na prevenção de doenças que se infiltram no organismo pela boca. Os autores também deram grande importância à criação da especialidade de odontogeriatria, apesar de afirmarem que os idosos não devem ser atendidos apenas por especialistas, mas sim, por clínicos gerais com formação odontogeriátrica, o que implica na inserção da odontogeriatria no currículo de graduação.

Oliveira et al. (2002) realizaram um estudo sobre o perfil do paciente odontogeriátrico da Faculdade de Odontologia de Bauru - USP e observaram que $36,17 \%$ dos idosos entrevistados consideraram que a condição bucal afeta de alguma forma a sua qualidade de vida. Afirmaram que não existe saúde geral sem saúde bucal e que a odontogeriatria deve, através da prevenção e tratamento odontológicos de indivíduos com doenças ou alterações sistêmicas, permitir que a população envelheça com saúde. É necessário que se mude a idéia de que o edentulismo é uma conseqüência do envelhecimento. 
Gavazzi e Krause (2002) realizaram um estudo sobre o envelhecimento e a infecção. Para eles as infecções nos idosos não são só mais freqüentes e mais severas como também têm características distintas em relação aos aspectos clínicos, resultados laboratoriais, epidemiologia, tratamento e controle. As razões para o aumento da susceptibilidade incluem elementos epidemiológicos, imunosenescência e má alimentação, bem como alterações anatômicas e fisiológicas relacionadas à idade. $\mathrm{O}$ envelhecimento pode ser a causa da infecção, mas a infecção também pode ser a causa do envelhecimento através da exacerbação da inflamação, destruição tecidual patógeno dependente e o envelhecimento acelerado. $O$ grande desafio do século é o cuidado ao idoso, a esta população em crescimento. A infecção no idoso é diferente daquela do jovem, pois apresenta uma maior diversidade de patógenos e tem poucos sintomas quando comparada à infecção em jovens. Os sinais mais comuns são manifestações não muito específicas como delírio, anorexia e mal estar. O aumento da sensibilidade à infecção também tem relação com a imunosenescência. O que se refere à noção de que uma disfunção do sistema imune relacionada à idade aumenta o risco de infecção. Uma diminuição no sistema imune do idoso existe tanto em relação à produção de anticorpos como as respostas proliferativas das células $T$, que estão claras na reativação da tuberculose e na diminuição da eficiência da vacinação da gripe (influenza). Há um consenso de que não há diminuição no número de células imunes com o envelhecimento. Mas há alterações funcionais em algumas das células como apresentado na tabela abaixo. 
Tabela 2.2 - Alterações funcionais celulares durante o envelhecimento

\begin{tabular}{|c|c|}
\hline Elementos do sistema imune & Modificações \\
\hline Granulócitos & $\begin{array}{l}\text { Neutrofilia normal durante a infecção aguda; } \\
\text { possibilidade de decréscimo na fagocitose; }\end{array}$ \\
\hline Monócitos, macrófagos e citocinas & $\begin{array}{l}\text { Possibilidade de alterações na secreção de } \\
\text { citocinas; }\end{array}$ \\
\hline Células NK & $\begin{array}{l}\text { Decréscimo na função e em resposta a } \\
\text { estimulação por citocinas; }\end{array}$ \\
\hline Linfócitos T & $\begin{array}{l}\text { Involução tímica, decréscimo da resposta } \\
\text { Th1, aumento da resposta Th2 e prejuízo da } \\
\text { proliferação de células T; }\end{array}$ \\
\hline Linfócitos B & $\begin{array}{l}\text { Decréscimo na produção de anticorpos } \\
\text { específicos e aumento da produção de auto } \\
\text { anticorpos; }\end{array}$ \\
\hline
\end{tabular}

Tenovuo (2002) estudou os agentes antimicrobianos da saliva como uma proteção do corpo todo. Isto iniciou em 1960 e 70 o que levou ao interesse pela saliva como um meio diagnóstico tanto de doenças locais quanto sistêmicas. Este interesse pela proteção dada pela saliva também se estende à proteção do sistema imune de mucosas. Concluiu que os agentes salivares(peroxidase salivar) também protegem o trato digestivo alto, não só a cavidade oral. O fator de crescimento epidérmico da saliva tem importante papel no reparo e manutenção do trato gastrointestinal. Portanto, a saliva não protege apenas a saúde oral ,mas também, a geral. 
Tlaskalová-Hogenová et al. (2002) realizaram um estudo sobre o papel da imunidade de mucosa na defesa e na alergia. O sistema imune de mucosa recobre a maior área do corpo, 200 a 300 metros quadrados, e envolve mecanismos de distinção entre os antígenos inofensivos, comensais e patógenos perigosos. O sistema imune de mucosa inato é representado pelas células epiteliais e mucosas e seus produtos, é capaz de reconhecer por padrão de receptores. As características que distinguem a imunidade de mucosa da sistêmica são: maior desenvolvimento de mecanismos de defesa inata, existência de populações características de tipos únicos de linfócitos, colonização de glândulas mucosas e exócrinas por células originadas de tecidos mucosos e indução preferencial da inibição de respostas a antígenos não perigosos (tolerância). Muitas doenças crônicas, incluindo a alergia, podem ocorrer como resultado de mudanças genéticas ou induzidas pelo ambiente nos mecanismos regulatórios da imunidade mucosa e tolerância, o que leva a uma resposta exagerada e generalizada a antígenos, alérgenos, superantígenos e mitógenos mucosos. A habilidade do sistema de distinção dos antígenos perigosos e não perigosos, é essencial para montar resposta imune protetora. Enquanto a pele tem várias camadas de células epiteliais, a mucosa tem somente uma. Diante disto, a mucosa necessita de uma proteção mais efetiva. Dessa forma, ela é protegida por um sistema especializado que envolve a maioria das células imunes ativas. As superfícies mucosas possuem vários mecanismos antibacterianos, entre eles está a $\lg \mathrm{A}$ secretória que bloqueia o ataque bacteriano à células mucosas.

Cieslak, Frost e Klentrou (2003) realizaram um estudo sobre os efeitos da atividade física, gordura corporal e cortisol salivar na imunidade de mucosa de crianças. 
Foram analisadas 50 crianças, com idades entre 10 e 11 anos, sendo 29 meninos e 32 meninas. As crianças foram submetidas a 20 metros de corrida, foi mensurada gordura corpórea e foram utilizados questionários para determinar relação das atividades físicas com variações e freqüências de infecção do trato respiratório superior. Foram coletadas amostras de saliva para análise de cortisol e IgA. As crianças foram monitoradas por 48 horas para se avaliar a atividade física exercida neste período. Aquelas que dedicavam mais tempo à atividades físicas reportaram menos dias doentes, enquanto que as que apresentaram mais de $25 \%$ de níveis de gordura corpórea reportaram mais dias doentes. Não houve diferença entre gêneros em relação aos níveis de IgA, freqüência de infecção do trato respiratório superior e níveis de cortisol. Portanto, a imunidade mucosa apresentou relação apenas com o nível de atividade física e com o nível de gordura corpórea.

Hamalainen et al. (2003) realizaram um estudo sobre a relação da saúde bucal com a mortalidade, ou seja, o papel da saúde bucal como fator predisponente à mortalidade utilizando análise de curvas de sobrevivência. Os resultados mostraram que quanto mais elementos dentais o indivíduo possuir, menor o seu risco de vir a falecer. $O$ efeito da perda dental foi significante após ajustar as variáveis de saúde geral. No entanto, os autores observaram que outros fatores também influenciam ra relação saúde dental e mortalidade, como o fumo e hábitos alimentares. Concluíram que uma pobre saúde dental está relacionada com o aumento da mortalidade em indivíduos idosos. 
Klein (2004) realizou uma revisão sobre a influência dos mecanismos imunológicos e hormonais nas diferenças das infecções parasitárias entre os sexos. A prevalência e intensidade das infecções causadas por protozoários, nematóides, trematóides, cestóides e artrópodes é maior nos machos que nas fêmeas. A primeira hipótese desta revisão é que existem diferenças imunológicas entre os sexos que devem estar influenciando esse maior parasitismo nos machos. Muitos estudos já observaram relação entre alterações na função imune e os hormônios circulantes. No entanto, tanto os hormônios do hospedeiro podem afetar as respostas à infecção, quanto os parasitas podem produzir ou alterar as concentrações de hormônios de seus hospedeiros. Além disso, o autor afirma que se há diferenças das respostas imunes entre os sexos, deve haver também diferença de resposta ao tratamento. Os machos são mais susceptíveis a muitos parasitas, mas existem outros parasitas para os quais os machos possuem maior resistência (ex. Toxoplasma gondii). Essa maior susceptibilidade à infecção pode ser uma das causas para a maior taxa de mortalidade em homens. Considerando várias espécies de hospedeiros (humanos, roedores, pássaros e lagartos) a taxa de infecção dos machos é maior para protozoários e nematóides. Estudos em roedores apresentaram que a castração reduz a mortalidade dos machos por infecção, enquanto que a administração de testosterona aumenta esta taxa. E quando administrado às fêmeas adultas, o testosterona induz a redução da produção de anticorpos e diminui a histocompatibilidade das células do baço. Também foi observado que as respostas imunes inflamatórias são maiores nas fêmeas que nos machos, o que pode explicar o maior desenvolvimento de doenças reumáticas inflamatórias, como a artrite reumatóide e o lupus eritematoso sistêmico, em mulheres. 


\section{PROPOSIÇÃO}

Esta pesquisa tem como objetivo analisar a influência do envelhecimento e da perda dos elementos dentais nos níveis totais de imunoglobulina secretória do tipo A na saliva. 


\section{MATERIAL E MÉTODOS}

\subsection{Casuística}

Foram selecionados 76 pacientes, com idades entre 20 e 85 anos, de ambos os sexos e sem distinção de raça. Estes foram divididos em três grupos:

- Grupo I (Grupo controle): constituído por 30 pacientes adultos jovens, com idades entre 20 e 40 anos, com todos os elementos dentais presentes exceto os terceiros molares e que foram previamente triados no consultório particular da pesquisadora;

-Grupo II: constituído por 16 pacientes idosos, com idades entre 65 e 78 anos, portadores de prótese total unimaxilar e que foram previamente triados no Hospital Universitário da Universidade de São Paulo para atendimento na Disciplina de Prótese Total da FOUSP;

-Grupo III: constituído por 30 pacientes idosos, com idades entre 65 e 87 anos, portadores de prótese total bimaxilar e que foram previamente triados no Hospital Universitário da Universidade de São Paulo para atendimento na Disciplina de Prótese Total da FOUSP; 
Para a seleção dos pacientes foram realizados minuciosa anamnese e exame clínico bucal, a fim de possibilitar a distribuição destes nos grupos acima descritos, e observar os seguintes fatores relevantes: bom estado clínico de nutrição, ausência de doenças sistêmicas que alterem os níveis de imunoglobulina a serem mensurados (exs: imunodeficiências, diabetes,...), ausência de lesões na mucosa oral e o não uso de antibióticos no período de três meses.

\subsection{Material}

4.2.1 materiais e instrumental para a anamnese e exame clínico bucal

- Ficha clínica especificamente formulada para a pesquisa (Anexo B)

- Caneta esferográfica azul

- Caneta esferográfica vermelha

- Lápis comum

- Espelho clínico

- Pinça clínica

- Sonda exploradora 
4.2.2 materiais para a coleta das amostras de saliva

- Recipientes de coleta plásticos descartáveis

- Recipiente comum, com gelo, para transporte das amostras

4.2.3 aparelho de armazenamento das amostras

- Freezer com temperatura de $-70^{\circ} \mathrm{C}$ (Scien Temp, Adrian, Michigan USA)

4.2.4 materiais e equipamentos utilizados para determinação dos níveis de Imunoglobulina A secretória salivar através da técnica de ELISA

A determinação dos níveis totais de $\lg A$ secretória salivar foi realizada através de ensaio imunoenzimático em fase sólida (ELISA - Enzyme-linked Imunosorbent Assay), descrito por Nagao, Ramos e Pereira (1990).

- Pipetas automáticas (Finnpipette)

- Placas de poliestireno (Costar, cód.3590, USA)

- Anti-lgA total (Sigma, cód.I0884, USA) 
- Solução salina tamponada com fosfato (PBS)

- Filme plástico (Magipack*)

- Depósito plástico comum

- Papel toalha

- Freezer comum (Prosdócimo)

- Eppendorfs (frascos para amostras)

- Agitador magnético

- Centrífuga 5403 (Eppendorf)

- Tubos de ensaio

- Estante para tubos de ensaio

- Erlemeyer

- Becker

- Tween 20 (Sigma, cód. P1379, USA)

- Padrão de IgA secretória (Sigma, cód. I2636, USA)

- Tampão PBS NaCl 0,5M e Tween 20 0,1\%

- Estufa (Nova ética)

- Conjugado de anti-IgA humana marcado com peroxidase (HRPO) (Sigma, cód. A0295, USA)

- Solução de substrato contendo ortofenilenodiamina (OPD) $(0,4 \mathrm{mg} / \mathrm{ml}$, Sigma, Cód. P8287, USA) em tampão de citrato-fosfato de sódio $0,1 \mathrm{M}, \mathrm{pH}$ 5,0 e peróxido de hidrogênio a 0,04\% de concentração final (Merck)

- Papel alumínio

- Solução de $\mathrm{H}_{2} \mathrm{SO}_{4} 2,5 \mathrm{M}$

- Leitor de placas (Labsystems Multiskan, USA) 
4.2.5 o utros materiais e equipamentos utilizados

\author{
- Afastador bucal \\ - Equipamento de Proteção Individual (luvas, máscara, avental e gorro \\ descartáveis)
}

\title{
4.3 Métodos
}

Consentimento esclarecido

O paciente recebeu informações sobre o projeto, seus objetivos e métodos, anterior ao início do trabalho, sendo consultado sobre sua voluntariedade em participar da pesquisa. Após seu consentimento, assinou o termo (Anexo C) autorizando sua participação.

Após esta etapa foram realizados a anamnese e o exame clínico da cavidade oral do paciente.

4.3.1 anamnese 
A anamnese foi realizada por meio de um questionário especificamente formulado para a pesquisa. Teve a finalidade de possibilitar a seleção e a distribuição dos pacientes nos grupos anteriormente descritos.

\subsection{2 exame clínico bucal}

O exame clínico foi realizado com auxílio de um espelho clínico, pinça clínica e sonda exploradora $n^{\circ}$ 5. Teve a finalidade de possibilitar a seleção e a distribuição dos pacientes nos grupos anteriormente descritos.

4.3.3 coleta das amostras de saliva para análise imunológica

Foi utilizado o método convencional de coleta onde os pacientes depositaram a saliva voluntariamente em recipientes plásticos de coleta. Para isto receberam a orientação de estar em jejum no mínimo, duas horas e meia.

Estas amostras foram transportadas para o Laboratório de Imunologia de Mucosas do Instituto de Ciências Biomédicas III da Universidade de São Paulo, em um recipiente comum com gelo, onde foram mantidas em freezer a $-70^{\circ} \mathrm{C}$ até a realização das dosagens. 
4.3.4 determinação dos níveis de IgA secretória através da técnica de ELISA

A determinação dos níveis totais de $\lg A$ secretória salivar foi realizada por meio de ensaio imunoenzimático em fase sólida (ELISA - Enzyme-linked Imunosorbent Assay), descrito por Nagao, Ramos e Pereira (1990).

Foram utilizadas placas de poliestireno (Costar, USA) que foram recobertas com 100 $\mu$ l de 5,0mg/l de anti-lgA total (Sigma, USA) em tampão PBS pH7,4 durante 16 horas a $4^{\circ} \mathrm{C}$. Após três lavagens com solução salina tamponada com fosfato (PBS) contendo $0,1 \%$ de Tween 20, as amostras de saliva foram centrifugadas a 2500 rpm por 15 minutos a $20^{\circ} \mathrm{C}$, para que, posteriormente, concentrações crescentes do padrão de $\lg A$ secretória (3,9-250,0 $\mathrm{g} / \mathrm{l})$ (Sigma, USA) e das amostras de saliva diluídas em tampão PBS $\mathrm{NaCl}$ 0,5M e Tween 20 0,1\% (1/4000, 1/8000, 1/16000, 1/32000) fossem incubadas nos poços em duplicatas durante 2 horas a $37^{\circ} \mathrm{C}$ em estufa.

Após três lavagens, o conjugado de anti-IgA humana marcado com peroxidase (HRPO) (Sigma, USA) foi adicionado às placas (em diluição 1/5000 no mesmo tampão diluente) e incubado durante uma hora e meia a $37^{\circ} \mathrm{C}$. Após novas lavagens, solução do substrato contendo ortoferilenodiamina (OPD) a $0,4 \mathrm{mg} / \mathrm{ml}$ em tampão de citrato-fosfato de sódio 0,1M, pH5,0 e peróxido de hidrogênio a 0,04\% de concentração final foi adicionada aos poços da placa. Passados 30 minutos à temperatura ambiente, a reação foi interrompida pela adição de solução de $50 \mu l$ de $\mathrm{H}_{2} \mathrm{SO}_{4} 2,5 \mathrm{~N}$. Após esta etapa realizou-se a leitura colorimétrica em leitor de placas (Labsystems Multiskan, USA), no comprimento de onda de 492nm (Bio Tek, USA). Por fim, os resultados foram expressos em $\mu \mathrm{g} / \mathrm{ml}$. 


\subsection{Análise Estatística}

Foi realizada uma análise de variância de ANOVA com dois fatores: sexo e grupo - para verificar o efeito significante da interação destes fatores. Depois, com o objetivo de se detectar onde se encontravam as diferenças, foram feitas comparações múltiplas com o auxilio do método de Bonferroni. 


\section{RESULTADOS}

A amostra foi constituída por 30 pacientes, grupo controle, adultos jovens totalmente dentados $(39,5 \%) ; 30$ pacientes idosos desdentados totais $(39,5 \%)$ e por 16 pacientes parcialmente desdentados $(21,0 \%)$. Os pacientes adultos apresentaram idade média de 26,5 anos (desvio padrão = 5,5 anos) sendo a idade mínima de 20 anos e idade máxima de 40 anos; há um paciente sem informação de idade. No grupo desdentado total, portadores de próteses totais bimaxilares,a idade média foi de 74,2 anos (desvio padrão = 5,6 anos); a idade mínima observada foi de 65 anos e a máxima de 87 anos. Já o grupo parcialmente desdentado, portadores de próteses totais unimaxilares, apresentou idade média de 70,8 anos (desvio padrão $=4,5$ anos) sendo a menor idade de 65 anos e a máxima de 78 anos.

Tabela 5.1- Amostragem: idade, número de pacientes e condição bucal

\begin{tabular}{|c|c|c|c|c|c|c|}
\hline \multicolumn{7}{|c|}{ Idade } \\
\hline Mínima & Máxima & Média & $\begin{array}{c}\text { Número de } \\
\text { pacientes }\end{array}$ & Avaliação bucal & $\begin{array}{c}\text { desvio } \\
\text { padrão }\end{array}$ & $\%$ \\
\hline 20 & 40 & 26,5 & 30 & $\begin{array}{l}\text { totalmente dentados } \\
\text { grupo controle } \\
\end{array}$ & 5,5 anos & 39,5 \\
\hline 65 & 87 & 74,2 & 30 & $\begin{array}{l}\text { desdentados totais } \\
\text { p.total bimaxilar }\end{array}$ & 5,6 anos & 39,5 \\
\hline 65 & 78 & 70,8 & 16 & $\begin{array}{c}\text { parcialmente desdentados } \\
\text { p. total unimaxilar }\end{array}$ & 4,5 anos & 21 \\
\hline
\end{tabular}


A distribuição dos grupos com relação ao gênero pode ser observada na Tabela 5.2 de onde se pode observar que a distribuição de sexo entre os grupos foi homogênea $(p=0,926)$.

Tabela 5.2- Distribuição de pacientes segundo gênero e grupo

\begin{tabular}{ccccc}
\hline \multicolumn{5}{c}{ Grupo } \\
\hline Gênero & Adulto & Bimaxilares & Unimaxilares & Total \\
\hline Feminino & $21(70 \%)$ & $21(70 \%)$ & $12(75 \%)$ & $54(71 \%)$ \\
\hline Masculino & $9(30 \%)$ & $9(30 \%)$ & $4(25 \%)$ & $22(29 \%)$ \\
\hline Total & $30(100 \%)$ & $30(100 \%)$ & $16(100 \%)$ & $76(100 \%)$ \\
\hline
\end{tabular}

Tabela 5.3-Medidas descritivas de SIgA segundo grupo e sexo

\begin{tabular}{lcccccc}
\hline & \multicolumn{2}{c}{ Controle } & \multicolumn{2}{c}{ Bimaxilares } & \multicolumn{2}{c}{ Unimaxilares } \\
\cline { 2 - 7 } $\begin{array}{l}\text { Medidas } \\
\text { Descritivas }\end{array}$ & $\begin{array}{c}\text { Feminino } \\
(\mathrm{n}=21)\end{array}$ & $\begin{array}{c}\text { Masculino } \\
(\mathrm{n}=9)\end{array}$ & $\begin{array}{c}\text { Feminino } \\
(\mathrm{n}=21)\end{array}$ & $\begin{array}{c}\text { Masculino } \\
(\mathrm{n}=9)\end{array}$ & $\begin{array}{c}\text { Feminino } \\
(\mathrm{n}=12)\end{array}$ & $\begin{array}{c}\text { Masculino } \\
(\mathrm{n}=4)\end{array}$ \\
\hline Média & 249,74 & 409,23 & 391,80 & 234,06 & 505,95 & 228,33 \\
$\begin{array}{l}\text { Desvio } \\
\text { padrão }\end{array}$ & 107,04 & 282,24 & 283,76 & 104,58 & 593,68 & 135,07 \\
Mediana & 274,90 & 415,70 & 279,20 & 222,00 & 309,40 & 224,06 \\
Mínimo & 109,00 & 83,60 & 71,40 & 76,30 & 73,05 & 71,40 \\
Máximo & 522,06 & 972,80 & 889,20 & 381,77 & 2220,00 & 393,80 \\
\hline
\end{tabular}

Observa-se que para o grupo controle, os homens apresentaram SIgA médio maior do que o apresentado pelas mulheres. Já, para os grupos bimaxilares e unimaxilares observa-se um comportamento contrário ao do grupo controle, isto é, 
nesses grupos o SIgA médio das mulheres mostrou-se superior ao dos homens. Esse comportamento pode ser mais facilmente visualizado no Gráfico 5.1.

Gráfico 5.1-Perfil médio de SlgA segundo grupo e sexo

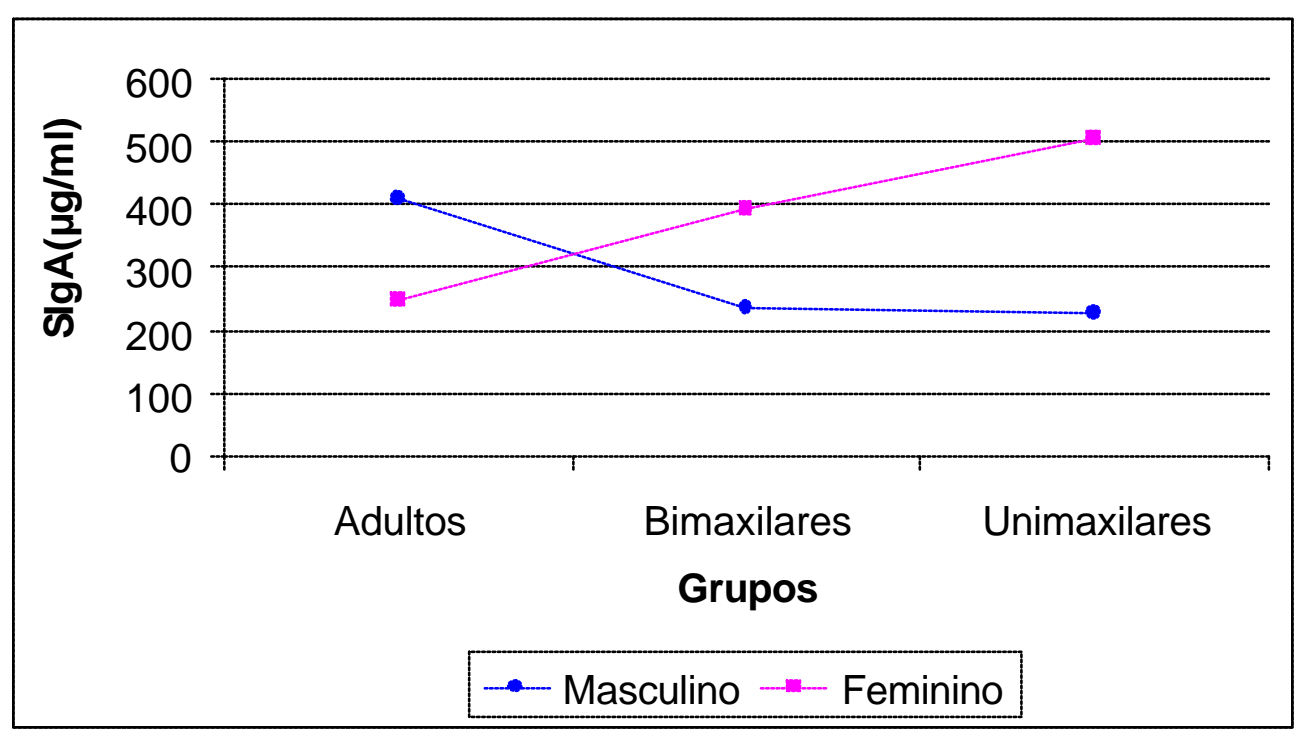

Por meio de uma análise de variância (ANOVA) com dois fatores (sexo e grupo) verificoutse efeito marginalmente significante da interação entre grupo e sexo ( $p=0,073$ ), ou seja, há uma tendência que os grupos não apresentaram, em média, o mesmo comportamento de SIgA entre homens e mulheres. Não foi observado efeito significante de grupo $(p=0,879)$, ou seja, em média os três grupos avaliados apresentaram o mesmo SlgA. Também não foi observado efeito significante de sexo ( $p=0,265)$, ou seja, em média, homens e mulheres apresentaram o mesmo SlgA. 
Observando-se a variação de SlgA na Tabela 5.3, nota-se que para o grupo unimaxilares o sexo feminino apresentou um desvio padrão muito alto quando comparado ao dos outros grupos. Isso ocorreu porque uma paciente desse grupo apresentou SIgA muito alto quando comparado aos demais. Dessa forma, optourse por refazer a análise anterior excluindo essa observação do conjunto de dados, ou seja, foi feita uma análise de sensibilidade para verificar se essa observação discrepante pode ter alguma influência nos resultados descritos anteriormente.

Tabela 5.4- Medidas descritivas de SIgA segundo grupo e sexo excluindo paciente com SIgA de 2220

\begin{tabular}{lcccccc}
\hline & \multicolumn{2}{c}{ Controle } & \multicolumn{2}{c}{ Bimaxilares } & \multicolumn{2}{c}{ Unimaxilares } \\
\cline { 2 - 7 } Medidas & $\begin{array}{c}\text { Feminino } \\
\text { Descritivas }\end{array}$ & $\begin{array}{c}\text { Masculino } \\
(\mathrm{n}=21)\end{array}$ & $\begin{array}{c}\text { Feminino } \\
(\mathrm{n}=21)\end{array}$ & $\begin{array}{c}\text { Masculino } \\
(\mathrm{n}=9)\end{array}$ & $\begin{array}{c}\text { Feminino } \\
(\mathrm{n}=11)\end{array}$ & $\begin{array}{c}\text { Masculino } \\
(\mathrm{n}=4)\end{array}$ \\
\hline Média & 249,74 & 409,23 & 391,80 & 234,06 & 350,13 & 228,33 \\
Desvio padrão & 107,04 & 282,24 & 283,76 & 104,58 & 259,22 & 135,07 \\
Mediana & 274,90 & 415,70 & 279,20 & 222,00 & 240,50 & 224,06 \\
Mínimo & 109,00 & 83,60 & 71,40 & 76,30 & 73,05 & 71,40 \\
Máximo & 522,06 & 972,80 & 889,20 & 381,77 & 773,60 & 393,80 \\
\hline
\end{tabular}

De acordo com a Tabela 5.4 pode-se observar o mesmo comportamento descrito na Tabela 3, ou seja, a exclusão da paciente com valor de SIgA discrepante, quando comparado aos demais, fez com que a média desse grupo diminuísse, porém, ainda assim, observourse que para o grupo unimaxilar as mulheres parecem apresentar SIgA maior do que o apresentado pelos homens. O Gráfico 5.2 apresenta o mesmo comportamento observado no Gráfico 5.1 . 
Gráfico 5.2-Perfil médio de SIgA segundo grupo e sexo, excluindo paciente com SlgA = 2220

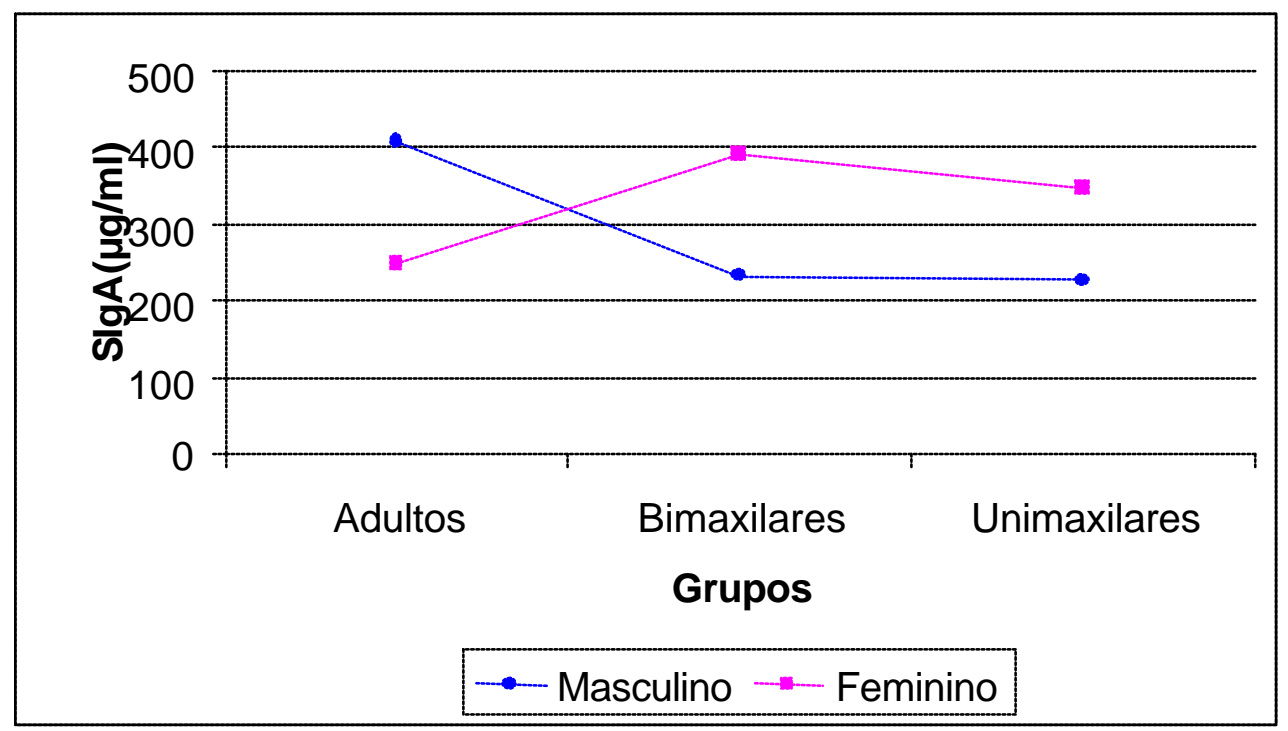

Por meio de uma análise de variância de ANOVA, com dois fatores (sexo e grupo), verificou-se efeito significante da interação entre grupo e sexo $(p=0,030)$, ou seja; em média, homens e mulheres não apresentaram o mesmo comportamento de SlgA nos grupos. Comparando com o resultado da análise anterior, verifica-se que o efeito ora descrito como marginalmente significante foi confirmado. Com o objetivo de se detectar onde se encontravam as diferenças, foram feitas comparações múltiplas com o auxílio do método de Bonferroni. Para o grupo controle, em média o SlgA de homens foi maior do que o de mulheres $(p<0,05)$. Para o grupo bimaxilar observourse que o $\operatorname{SIgA}$ de mulheres foi maior do que o dos homens $(p<0,05)$. Já para o grupo unimaxilar não foi observada diferença de SIgA entre homens e mulheres $(p>0,05)$. 
Comparando-se o SIgA do grupo controle com o do grupo bimaxilar observourse diferença significante no sexo feminino $(p<0,05)$; já para os homens não foi detectada diferença estatisticamente significante $(p>0,05)$. Comparando-se o grupo bimaxilar com o unimaxilar não foi observada diferença estatisticamente significante do SIgA nem entre homens nem entre mulheres $(p>0,05)$. 


\section{DISCUSSÃO}

Na presente pesquisa foram utilizadas amostras de saliva para análise dos níveis de SIgA. Esta é um modelo de grande importância que reflete adequadamente a condição do sistema imune de mucosa. A metodologia da coleta da saliva realiza-se de forma não invasiva, sendo também útil para monitorar respostas antigênicas e fisiológicas. Pode, ainda, ser utilizada para seguir o progresso de pacientes em tratamento (GLEESON; CRIPPS; CLANCY, 1995; STRECKFUS; BIIGLER, 2002).

Foram selecionados 46 idosos saudáveis no intuito de remover possíveis influências de doenças crônicas que podem alterar parâmetros imunológicos importantes, como os níveis de IgA (FRANCESCHI et al., 1995). Foram excluídos os portadores de diabetes, em função da alteração das glândulas salivares pela doença (BEN-ARYECH; COHEN,1988). Porém, há um consenso quanto à não influência desta patologia sobre os níveis de IgA salivar (BEN-ARYECH; COHEN, 1988; ROSA; ROCHA; LOPES, 1993; STRECKFUS et al., 1994). Foram excluídos idosos portadores de hipertensão arterial porque acredita-se que estes apresentam uma diminuição da secreção de SIgA (STRECKFUS; WELSH; STRAHL,1991).

Nesta investigação os idosos imunologicamente normais não apresentaram efeito significante de grupo $(p=0,879)$, ou seja, em média, os três grupos avaliados apresentaram o mesmo nível total de lgA secretória salivar, corroborando com Gronblad 
e Lindholm (1987), Aguirre et al. (1987), Smith, Taubman e Ebersole (1987) e Hayflick (1994). Apesar das evidências do não envolvimento dos fatores perda dental e envelhecimento em relação aos níveis totais de $\lg A$ secretória salivar, deve-se ter o cuidado para não se fazer uma afirmação conclusiva a este respeito.

Sabe-se que a perda dental influância na saúde geral do indivíduo, principalmente nos aspectos nutricionais, sociais e psicológicos. Esta perda pode ocorrer em decorrência de diversos fatores, como por exemplo, a diminuição do fluxo salivar, que tem como conseqüência uma maior incidência de cárie radicular (MANN et al., 1990). Esta diminuição da secreção salivar pode ocorrer como conseqüência do processo de envelhecimento (STORCH; BELLAGAMBA, 1982;SMITH et al., 1992; LOPEZ-JONNET; BERMIJO-FENOLL, 1994; WERNER et al., 1998) ou em decorrência do uso de medicações (STRECKFUS; WELSH; STRAHL, 1991; PADILHA et al., 1998a; CHIAPPELLI et al., 2002). No entanto, outros autores (SMITH; EBERSOLE; TAUBMAN, 1983) observaram um aumento do volume salivar em hamsters idosos. Apesar da diminuição da secreção salivar o envelhecimento não reduz o fluxo salivar total (HAYFLICK, 1994) nem o parotídeo (TENOVUO, 1992).

Considerando-se os aspectos nutricionais, observamos que a perda dos elementos dentais e outras patologias buco-dentais determinam a falência da capacidade mastigatória alterando a saúde geral do paciente (MADEIRA; CAETANO; MINATTI, 1987; EKELUND, 1989; MORIGUCHI, 1992; CASTILHOS, 2001). O número e a disposição dos elementos dentais têm relação direta com o que os idosos comem (MCGRATH; BEDI, 1999; CHIAPPELLI et al., 2002), muitos optam por consumir 
alimentos menos consistentes tendendo a má nutrição (EKELUND, 1989). Uma menor quantidade de proteína é associada com um significante prejuízo da imunidade celular, da função fagocítica, do sistema complemento, da concentração de $\lg A$ secretória e da produção de citocinas (CHANDRA, 2002). Muitas doenças sistêmicas e condições como a imunodeficiência e deficiência de vitaminas são manifestadas na boca (SLAVKIN, 2000)

Em relação ao aspecto social, Moriguchi (1992) concluiu que a perda dental associada a uma menor atividade social provoca o envelhecimento cerebral, pois, aumenta o fator de risco da aterosclerose desta estrutura. Também foi observado por Maupomé e MacEntee (1998) que a maioria dos usuários de prótese total tinham renda alta ou, o suficiente para suprir suas necessidades, o que sugere que o estado econômico pode atuar de maneira inversa sobre o estado dental. Um fator importante na predisposição à doenças geriátricas, que deve ser acrescentado, é o emocional, relacionado à auto estima, como mencionam outros autores (MARCUS et al., 1996; MAUPOMÉ; MACENTEE, 1998; MCGRATH; BEDI, 1999; SALIBA et al., 1999; MADEIRA; MADEIRA, 2000; CASTILHOS, 2001).

Quando se considera o indivíduo como um todo, muitos autores (MARCUS et al., 1996; SOUZA; TAMAKI, 1996; PADILHA; SOUZA, 1997; SLAVKIN, 2000; CHIAPPELLI et al., 2002; TENOVUO, 2002) observaram que a saúde geral é afetada pela condição oral do indivíduo. A perda dos elementos dentais leva a um colapso do sistema estomatognático e, a manutenção do equilíbrio sistêmico depende diretamente das condições geral e oral, pois, uma pode predispor à outra. Alguns autores (JANSSON; 
LAVSTEDT; FRITHIOF, 2002; HAMALAINEN \& al., 2003) observaram existência da relação entre a pobre condição de saúde bucal do indivíduo e o risco de mortalidade.

Portanto, a saúde bucal está relacionada diretamente com a qualidade de vida do idoso, o que já é aceito pelos próprios idosos segundo estudos realizados por Marcus et al., (1996), Padilha et al., (1998), Werner et al., (1998), Padilha et al., (1998a), McGrath e Bedi,(1999) e Castilhos et al., (2001).

Dessa forma, observa-se a importância do Cirurgião Dentista na orientação dos indivíduos, acerca da necessidade de manutenção dos elementos dentais, principalmente realizadas por campanhas de promoção de saúde bucal, visando um futuro mais saudável (FRARE et al., 1997; WERNER et al., 1998; SALIBA et al., 1999; MANETTA; BRUNETTI; MONTENEGRO, 1999; SEQUEIRA; BRUNETTI, 2002), desvinculando a perda dental do envelhecimento (STORCH; BELLAGAMBA, 1982; EKELUND, 1989; MARCUS et al., 1996; PADILHA et al., 1998a; MADEIRA; MADEIRA, 2000; OLIVEIRA et al., 2002).

O envelhecimento atua diretamente alterando algumas funções como a respiratória, que reduz em 50\% sua capacidade operacional (DICE, 1993), portanto, levando à perda de reservas físicas e aumento da propensão ao trauma, à infecção e às doenças crônicas (STORCH; BELLAGAMBA, 1982; WEKSLER, 1995; PERCIVAL; MARSH; CHALLACOMBE, 1997; MCARTHUR, 1998). O envelhecimento pode ser a causa de infecção, mas, a infecção também pode ser a causa do envelhecimento, que ocorre pela exacerbação da inflamação, destruição tecidual patógeno dependente e o 
envelhecimento acelerado (GAVAZZI; KRAUSE, 2002). Porém, Miloro e Mc Cormick (1996), observaram que a seqüência normal de reparo cicatricial é mantida nos idosos, o que corrobora com Padilha et al. (2000), apesar de apresentar alterações de intensidade em determinadas etapas, como uma diminuição na migração de fibroblastos e na síntese de colágeno.

Considerando-se o sistema imune, o envelhecimento leva a uma maior dificuldade dos idosos em montar respostas imunes específicas (SMITH; EBERSOLE; TAUBMAN, 1983; SMITH; TAUBMAN; EBERSOLE, 1987; TENOVUO, 1992; HAYFLICK, 1994; BREITBART; STOLLAR, 2000; FUJIHASHI et al., 2001), o que pode ser associado à mudanças no número ou função dos linfócitos $T$ ou $B$ ou células apresentadoras de antígeno e/ou pode ser resultado dos menores níveis de exposições a estes antígenos (SMITH; TAUBMAN; EBERSOLE, 1987). Já Harrod,Martin e Russell (2001) observaram, em ratos, a manutenção da habilidade de montar respostas imunes. Também há aumento de autoanticorpos (WEKSLER, 1995; HAYFLICK, 1994; YUNG, 2000; BREITBART; STOLLAR, 2000) e dificuldade em se induzir a tolerância oral (VAZ et al., 1997).

A concentração total das imunoglobulinas, em especial a $\operatorname{lgA}$ secretória, é estudada em relação à idade de várias formas. Quando se considera a comparação entre crianças e adultos há um consenso de que esta concentração total de $\lg A$ salivar aumenta com o passar dos anos (SMITH, TAUBMAN; EBERSOLE, 1987; GRONBLAD; LINDHOLM, 1987; TAPPUNI; CHALLACOMBE, 1994), o que não ocorre quando se compara adulto jovem e idoso, onde alguns autores afirmam que não há alteração dos 
níveis totais de IgA (SMITH; EBERSOLE; TAUBMAN, 1983; AGUIRRE et al., 1987; GRONBLAD; LINDHOLM, 1987; SMITH; TAUBMAN; EBERSOLE, 1987; KOGA et al., 2000) e outros asseguram que estes aumentam (ARRANZ et al., 1992; CHALLACOMBE; PERCIVAL; MARSH, 1995; PERCIVAL; MARSH; CHALLACOMBE, 1997; YUNG, 2000). Também são considerados os locais de origem da saliva estudada, pois, segundo Smith et al. (1992), quando se analisa a saliva labial inferior há diminuição na concentração de $\lg A$ nos idosos, enquanto que não ocorre alteração na saliva proveniente da parótida. Segundo Franceschi et al. (1995) o sistema imune sofre uma complexa remodelação antes de uma deteriorização e muitos parâmetros imunológicos que eram tidos como deterioráveis com a ação do tempo, em indivíduos saudáveis, não sofrem alteração, o que corrobora com McArthur (1998) e Breitbart e Stollar (2000). Weksler (1995) denomina esta remodelação de disregulação do sistema imune.

O processo de envelhecimento possui também influência sobre os tecidos bucais tornando os dentes mais frágeis aumentando o risco de fratura, aumentando a incidência de cáries radiculares, diminuindo a elasticidade da mucosa oral e reduzindo a função das glândulas salivares (STORCH; BELLAGAMBA, 1982; FIGUEIREDO; YURGEL; LORANDI, 1990).

A comparação e relação com outros trabalhos da literatura é difícil pelos diferentes grupos etários, diferentes objetivos e outras variáveis como: estimulação salivar (PROCTOR; CARPENTER, 2001), coleta e armazenagem da saliva, origem desta saliva, método de identificação dos anticorpos e outros fatores. Além disso, é 
importante ressaltar que o presente trabalho é uma descrição dos anticorpos salivares em um determinado momento da vida do indivíduo, e que as mudanças relacionadas com a idade ocorrem nas diferentes partes do corpo em tempos diferentes (HAYFLICK, 1994). O que, segundo Gleeson, Cripps e Clancy (1995), tem muita importância, pois a medida de IgA é utilizada para mensurar a integridade do sistema imune mucoso humano. Isto pois, a IgA secretória é um dos mecanismos antibacterianos das superfícies mucosas que bloqueia o ataque bacteriano às células mucosas (NASPITZ et al., 1999; TLASKALOVÁ-HOGENOVÁ et al., 2002; NIEUW AMERONGEN; VEERMAN, 2002; TENOVUO, 2002). É provável que as concentrações de IgA secretória possam variar consideravelmente no decorrer do tempo e sejam influenciadas por vários aspectos não mensuráveis como o nível de stress e outros aspectos psicológicos. As variações também podem ocorrer de acordo com fatores como o fluxo salivar, o ph, e a higiene oral.

A presença de elementos dentais, a idade e a forma de alimentação do indivíduo foram estudadas em relação à concentração salivar de IgA. Concluíram que as concentrações eram alteradas principalmente em relação à idade (TAPPUNI; CHALLACOMBE, 1994).

O uso de próteses removíveis com recobrimento de palato também afeta as concentrações de IgA, aumentando-as quando o fluxo salivar é menor (LAPPALAINEN; YLFURPO; KNUUTTILA, 1985). 
O tabagismo pode alterar a concentração de $\lg \mathrm{A}$ desde que em doses acentuadas, o que leva a uma menor concentração desta imunoglobulina na saliva (MIGLIARE; MARCUCCI, 1993). No entanto, o hábito de fumar não apresentou influência sobre a secreção salivar (LOPEZ-JORNET; BERMEJO-FENOLL, 1994).

A localização da saliva também pode alterar o resultado da mensuração de lgA, como observado por Smith et al. (1992). O autor observou que a concentração de $\lg A$ na saliva oriunda da região labial inferior foi menor em indivíduos idosos, enquanto que a IgA da saliva parotídea não apresentou diferença em relação à idade dos indivíduos estudados.

Nesta pesquisa observou-se uma variabilidade muito grande dos dados obtidos para a concentração total de gA secretória, o que segundo McArthur (1998), ocorre devido a fatores ambientais e à diversidade genética da população, que são parcialmente responsáveis por esta variabilidade de dados obtidos em relação à imunosenescência em humanos. Também Yung (2000) afirma que há um grande grau de variabilidade nas respostas imunes dos indivíduos de todas as idades e que esta variabilidade aumenta com o processo de envelhecimento. Apesar desta variabilidade, Souza-Leão (1999) propõe a utilização do sistema imune como um biomarcador do processo de senescência.

A importância da odontogeriatria na formação profissional dos Cirurgiões Dentistas é considerada por vários autores (MADEIRA; CAETANO; MINATTI, 1987; PADILHA et al., 1998; MANETTA; BRUNETTI; MONTENEGRO, 1999; SHINKAI et al., 
2000; SEQUEIRA; BRUNETTI, 2002), principalmente devido ao rápido aumento da população idosa (KALACHE; VERAS; RAMOS, 1987; RAMOS; VERAS; KALACHE, 1987; WERNER et al., 1998) e a relação direta entre a saúde bucal e a qualidade de vida almejada por todos os indivíduos durante a vida (PADILHA et al., 1998; WERNER et al., 1998; MCGRATH; BEDI, 1999) . O número e a qualidade dos elementos dentais têm sido os mais freqüentes indicadores de saúde bucal utilizados pela epidemiologia (PADILHA; SOUZA, 1997)

Quando se analisou a influência do gênero nos resultados do presente trabalho, verificourse efeito significante da interação entre grupo e sexo $(p=0,030)$, ou seja; em média, homens e mulheres não apresentaram o mesmo comportamento de IgA nos grupos, diferente do resultado anteriormente observado nos grupos como um todo. Assim, encontrou-se um fator que influenciou os níveis de IgA: o gênero. Para o grupo controle, em média, o IgA de homens foi maior do que o de mulheres $(p<0,05)$. Para o grupo bimaxilar observouse que o IgA das mulheres foi maior do que o dos homens $(p<0,05)$. Já para o grupo unimaxilar não foi observada diferença de $\lg A$ entre homens $e$ mulheres $(p>0,05)$. A influência do gênero foi observada considerando-se os grupos separadamente, principalmente o controle e o totalmente desdentado. No entanto, quando se compara estes dois grupos, observa-se que a diferença foi significante apenas em relação ao sexo feminino. Comparando-se o grupo bimaxilar com o unimaxilar não foi observada diferença estatisticamente significante do $\lg A$ nem entre homens nem entre mulheres $(p>0,05)$. Ou seja: observou-se novamente que 0 fator perda dental não apresentou influência sobre os níveis de $\lg \mathrm{A}$, mesmo analisando os gêneros separadamente entre os dois grupos de idosos. No entanto, quando se analisa 
os dois fatores juntamente, ou seja, perda dental e envelhecimento, há diferença significante em relação ao sexo feminino.

Este nível total de IgA mais alto nas mulheres idosas levou a um detalhado estudo sobre o dimorfismo sexual da resposta imune. Observou-se que diversos autores apresentam esta vantagem das mulheres em relação aos homens, afirmando que elas possuem respostas imunes mais elevadas e uma maior síntese de imunoglobulinas, principalmente as específicas (BLAZKOVEC; ORSINI; MAGINN, 1973; SCHUURS; VERHEUL, 1990; VISELLI et al., 1995; VERTHELYI, 2001; KLEIN, 2004). No entanto, as fêmeas, de diversas espécies, apresentam também uma maior propensão ao desenvolvimento de doenças autoimunes pois, com o passar da idade, esta maior produção de anticorpos também ocorre em relação aos autoanticorpos. Além de que as respostas imunes inflamatórias são maiores nas fêmeas que nos machos, o que pode explicar o maior desenvolvimento de doenças reumáticas inflamatórias como a artrite reumatóide em mulheres (KLEIN, 2004). Estas diferenças também foram observadas comparando-se animais adultos jovens com idosos, ou seja, considerandose a influência da idade (BLAZKOVEC; ORSINI; MAGINN, 1973).

Muitos pesquisadores procuraram explicações para estes fatos nos hormônios sexuais e observaram que: os efeitos da pré ou pós puberal gonadectomia sobre a resposta imune primária sugeriram que a vantagem das fêmeas em relação a síntese de imunoglobulinas depende primariamente da relativa ausência dos hormônios gona dais masculinos (BLAZKOVEC; ORSINI; MAGINN, 1973); os hormônios sexuais masculinos intratimicamente afetam a geração do repertório de células $T$ maduras 
(OLSEN et al., 1994; VISELLlet al., 1995); a privação de andrógenos resulta em um decréscimo no número de células maduras periféricas do tipo $T$, em uma expansão do compartimento de células periféricas do tipo B e um aumento da capacidade de produção de autoanticorpos (VISELLI et al., 1995); os hormônios sexuais influenciam no desenvolvimento, maturação, ativação e morte das células imunes (VERTHELYI, 2001)

Também colabora com esta alta susceptibilidade masculina a maior ocorrência de alterações mucosas orais não relacionadas nem a idade nem ao uso de próteses inadequadas verificada por MacEntee, Glick e Stolar (1998) e uma maior taxa de mortalidade de origem infecciosa entre os homens observada por Klein (2004). Já Verthelyi (2001) apresenta, diferentemente dos demais autores, a presença de um efeito "protetor" dos andrógenos pois a orquidectomia dos machos resulta em morte prematura e, em contraste, a administração in vivo de estrógeno acelera a progressão de doenças e morte. Em contrapartida KLEIN (2004) apresenta que a castração reduz a mortalidade dos machos por infecção, enquanto que a administração de testosterona aumenta esta taxa. E quando administrado às fêmeas adultas induz a redução da produção de anticorpos e diminui a histocompatibilidade das células do baço.

Para Cieslak, Frost e Klentrou (2003) não há diferença entre os gêneros em relação aos níveis de $\lg A$ salivar quando se estuda crianças.

Estes estudos se tornam cada vez mais importantes devido ao grande número de pessoas, principalmente do sexo feminino, que estão utilizando hormônios sexuais como contraceptivos, em terapias de reposição ou suplementos alimentares. No 
entanto, segundo Verthelyi (2001) os hormônios sozinhos não são responsáveis pelo dimorfismo sexual apresentado pelo sistema imune.

Apesar de todo interesse voltado para o processo de envelhecimento, o conhecimento das várias alterações que ocorrem no sistema imune com o passar dos anos é ainda pouco desenvolvido e requer um número maior de estudos e uma especificidade maior. Assim também, foi observado que a influência do gênero nos níveis de IgA salivar merece maior atenção e dedicação em estudos posteriores. 


\section{CONCLUSÕES}

1. Analisando a influência dos fatores envelhecimento e perda dental observourse que em média, os três grupos avaliados apresentaram o mesmo nível total de imunoglobulina do tipo A secretória na saliva.

2. Apesar de não proposto, a influência do fator gênero nos níveis totais de imunoglobulina secretória do tipo A na saliva foi observada da seguinte forma:

-Em média, homens e mulheres não apresentaram o mesmo comportamento de $\lg A$ nos grupos.

-Para o grupo controle, em média o IgA de homens foi maior do que o de mulheres $(p<0,05)$.

-Para o grupo bimaxilar observourse que o IgA de mulheres foi maior do que $o$ dos homens $(p<0,05)$.

- O grupo unimaxilar não apresentou diferença de IgA entre homens e mulheres $(p>0,05)$. 
-Comparando-se o $\lg$ A do grupo controle com o do grupo bimaxilar observou-se diferença significante no sexo feminino $(p<0,05)$, o mesmo não ocorreu para os homens.

-Comparando-se o grupo bimaxilar com o unimaxilar não foi observada diferença estatisticamente significante do $\lg A$, nem entre homens nem entre mulheres $(p>0,05)$. 


\section{REFERÊNCIAS 1}

Aguirre A, Levine MJ, Cohen RE, Tabak LA. Immunochemical quantitation of .-amylase and secretory IgA in parotid saliva from people of various ages. Arch Oral Biol $1987 ; 32(4): 297-301$.

Arranz E, O’Mahony S, Barton JR, Ferguson A. Immunosenescence and mucosal immunity: significant effects of old age on secretory $\lg A$ concentrations and intraepithelial lymphocyte counts. Gut 1992;33(7):882-6.

Ben-Aryeh H, Cohen M. Salivary composition in diabetic patients. J Diab Complic 1988;(2):96-9.

Blazkovec AA, Orsini MW, Maginn PC. Sexual dimorphism in the primary immune response of the syrian hamster. Int Arch Allergy 1973;(44):274-93.

Breitbart E, Stollar D. Aging and the human immune system. Israel Medical Assoc J 2000;2(9):703-7.

Castilhos ED. A importância dos dentes e próteses para idosos de três diferentes grupos ou "O dia em que você ficar sem dentes você vai se lembrar de mim" [Dissertação de Mestrado]. Porto Alegre: Faculdade de Odontologia da Universidade Federal do Rio Grande do Sul;2001.

Challacombe SJ, Percival RS, Marsh PD, Age-related changes in immunoglobulin isotypes in whole and parotid saliva and serum in healthy individuals. Oral Microbiol and Immunol 1995;10(4):202-7.

Chandra RK. Nutrition and the immune system from birth toold age. Eur J Clin Nutr 2002;56 Suppl.(3):573-6.

\footnotetext{
${ }^{1}$ De acordo com Estilo Vancouver. Abreviatura de periódicos segundo Bases de Dados MEDLINE.
} 
Chiappelli F, Bauer J, Spackman S, Prolo P, Edgerton M, Armenian C et al. Dental needs of the elderly in the $21^{\text {st }}$ century. Gen Dent 2002;50(4):358-63.

Cieslak TJ, Frost G, Klentrou P. Effects of physical activity, body fat, and salivary cortisol on mucosal immunity in children. J Appl Physiol 2003;(95)2315-20.

Dice JF. Cellular and Molecular mechanisms of aging. Physiol Reviews 1993;73:149-59.

Ekelund R. Dental state and subjective chewing ability of institutionalized elderly people. Community Dent Oral Epidemiol 1989;17(1):24-7.

Figueiredo MA, Yourgel LS, Lorandi CS. Alterações fisiológicas freqüentemente presentes na cavidade bucal do paciente idoso. Rev Odonto Ciência 1990;5(10):57-61 .

Franceschi C, Monti D, Sansoni P, Cossarizza A. The immunology of exceptional individuals: the lesson of centenarians. Immunol Today 1995;(16):12-6.

Frare SM, Limas PA, Albare llo FJ, Pedot G, Régio RAS. Terceira idade: quais os problemas bucais existentes? Rev Assoc Paul Cir Dent 1997;51(6):73-6.

Fujihashi K, Kato H, Ginkel FW, Koga T, Boyaka PN, Jackson RJ et al. A revisit of mucosal IgA immunity and oral tolerance. Acta Odontol Scand 2001;59(5):301-8.

Gavazzi G, Krause KH. Ageing and infection. Lancet Infect Dis 2002;2:659-66.

GleesonM, Cripps AW, ClancyR. Modifiers of the human mucosal immune system. Immunol Cell Biol 1995;73:397-404.

Grönblad EA, Lindholm K. Salivary immunoglobulin concentrations in predentate and edentulous mouths. Scand J Dent Res 1987;95(1):27-31.

Hamalainen P, Meurman JH, Keiskinen M, Heikkinen E. Relationship between dental health and 10-year mortality in a cohort of community-dwelling elderly people. Eur $\mathrm{J}$ Oral Sci 2003;111(4):291-6. 
Harrod T, Martin M, Russell MW. Long-term persistence and recall of immune responses in aged mice after mucosal immunization. Oral Microbiol Immunol $2001 ; 16: 170-7$.

Hayflick L. How and why we age. New York: Ballantine; 1994.

JanssonL, Lavstedt S, Frithiof L. Relationship between oral health and mortality rate. J Clin Peiodontol2002;29:1029-34.

Kalache A, Veras RP, Ramos L R. O envelhecimento da população mundial. Um desafio novo. Rev Saúde Públ 1987;21(3):200-10.

Kiyono H, Kweon MN, Hiroi T, Takahashi I. The mucosal immune system: from specialized immune defense to inflammation and allergy. Acta Odontol Scand $2001 ; 59(3): 145-53$.

Klein SL. Hormonal and immunological mechanisms mediating sex differences in parasite infection. Parasite Immunol 2004;(26):247-64.

Koga T, McGhee JR, Kato H, Kato R, Kiyono H, Fujihashi K. Evidence for early aging in the mucosal immune system. J Immunol 2000;165:5352-9.

Lappalainen R, Yli-Urpo A, Knuuttila M. Removable dentures affect concentrations of protein, amylase and IgA in whole saliva among elderly men. Gerodontics 1985;1(6):277-80.

Lopez-Jornet MP, Bermejo-Fenoll A. Is the na age-dependent decrease in resting secretion of saliva of healthy persons? A study of 1493 subjects. Braz Dent J 1994;5(2):93-8.

McArthur WP. Effect of aging on immunocompetent and inflammatory cells.

Periodontology 2000 1998;16:53-79.

MacEntee MI, Glick N, Stolar E. Age, gender, dentures and oral mucosal disorders. Oral Dis 1998;4(1):32-6. 
McGrath C, Bedi R. The importance of oral health to older people's quality of life.Gerodontology 1999;16(1):59-63.

Madeira AA, Madeira LO paciente geriátrico e a complexidade de seu atendimento. Rev Bras Odontol 2000;57(6):350-1.

Madeira AA, Caetano M, Minatti EJ. Odontogeriatria: uma necessidade curricular. Rev Bras Odontol 1987;44(3):6-12.

Mann J, Mersel A, Eenest M, Labiv M. Dental behavioral aspects of noninstitucionalized elderly population. Gerontology 1990;9(3):83-8.

Manetta CE, Brunetti RF, Montenegro FL. B. Perspectiva da odontologia geriátrica. Rev Inst Cienc Saúde 1999;17(1):51-5.

Marcus PA, Joshi A, Jones JA, Morgano SM. Complete edentulism and denture use for elders in New England. J Prosth Dent 1996;76(3):260-6.

Maupomé G, MacE ntee MI. Prosthodontic profiles relating to economic status, social network and social support in an elderly population living endependently in Canada. $J$ Prosthet Dent 1998;80(5):598-604.

Migliari DA. Níveis da IgA secretória na saliva total não estimulada de indivíduos fumantes e não fumantes por imunodifusão radial simples [Dissertação de Mestrado]. São Paulo: Faculdade de Odontologia da USP; 1990.

Migliari DA, Marcucci G. Níveis da IgA secretória na saliva total não estimulada de indivíduos fumantes e não fumantes por imunodifusão radial simples. Rev Odontol da USP 1993;7(2):109-13.

Miloro M, McCormick S. Wound healing and Immunity. Atlas Oral Maxillofac Surg Clin North Am 1996;8(2):159-70.

Moriguchi Y. Aspectos geriátricos no atendimento odontológico. Odontol Moderno 1992;19(4):11-3. 
Nagao AT, Ramos OL, Pereira AB. Immuno assays of secretory IgA and secretory component. Braz J Med Biol Res 1990;23(3-4):211-24.

Naspitz GMCC, Nagao AT, Mayer MPA, Carneiro-Sampaio MMS. Anti-S mutans antibodies in saliva of children with different degrees of dental caries. Pediatr Allergy Immunol 1999;10:143-8.

Nieuw Amerongen AVN, Veerman ECI. Saliva - the defender of the oral cavity. Oral dis 2002;8(1):12-22.

Oliveira JA, Ribeiro EDP, Bonachela WC, Capelozza ALA. Perfil do paciente odontogeriátrico da Faculdade de Odontologia de Bauru - USP, PCL 2002;4(17):71-9.

Olsen NJ, Viselli SM, Shults K, Stelzer G, Kovacs WJ. Induction of immature thymocyte proliferation after castration of normal male mice. Endocrinology 1994;134(1):107-13.

Padilha DMP, Souza MAL. Estado dentário e edentulismo observados em dois grupos de idosos do Brasil e da Inglaterra. Rev Odonto Ciência 1997;12(24):67-85.

Padilha DMP, Baldisserotto J, Soll L, Bercht S. Odontogeriatria: em busca de novas definições. Ação Coletiva 1998a;1(3):24-6.

Padilha DMP, Baldisserotto J, Soll L, Bercht S, Petry P. Odontogeriatria na Universidade: para não perder tempo. Rev Fac Odontol Porto Alegre 1998;39(1):14-6.

Padilha DMP, Sanfelice JC, Rados PV, Bercini F, Azambuja TWF. Reparo de feridas na língua de camundongos jovens e velhos. Rev Fac Odontol Porto Alegre 2000;41(1):669.

Percival RS, Marsh PD, Challacombe SJ. Age-related changes in salivary antibodies to commensal oral and gut biota. Oral Micro biol Immunol 1997;12:57-63.

Proctor GB, Carpenter GH. Chewing stimulates secretion of human salivary secretory immunoglobulin A. J Dent Res 2001;80(3):909-13. 
RamosLR, Veras RP, Kalache A. Envelhecimento populacional: uma realidade brasileira. Rev Saúde Publ 1987; 21(3):211-24.

Rosa OPS, Rocha RSS, Lopes ES. Imunoglobulinas salivares e prevalência de cárie em portadores de diabetes mellitus insulino-dependentes. Rev Fac Odontol Bauru 1993;1(1-4):18-21.

Saliba CA, Saliba NA, Marcelino G, Moimaz SAS. Auto-avaliação de saúde na $3^{\circ}$ idade. RGO 1999;47(3):127-30.

Schenck K, Kiyono H, Helgeland K, Steinsvoll S, Taylor B. Proceedings of the conference "New frontiers in oral immunological diseases", Lillehammer, Normay, 2001. Acta Odontol Scand 2001a;59(3 Pt 1):121-3.

Schenck K, Kiyono H, Helgeland K, Steinsvoll S, Taylor B. Proceedings of the conference "New frontiers in oral immunological diseases", Lillehammer, Normay, 2001. Acta Odontol Scand2001b;59(4 Pt 2):209-11.

Schuurs AHWM, Verheul HAM. Effects of gender and sex steroids on the immune response. J Steroid Biochem 1990;35(2):157-72.

Sequeira E, Brunetti L. Eles merecem esforços redobrados. Rev ABO Nac 2002;10(3):142-3.

Shinkai RS, Cury AADB, Sayeg MA, Souza-Leão S. Abordagem interdisciplinar na formação do cirurgião dentista para a atenção integral à saúde do idoso. Rev Odonto Ciência 2000;15(30):85-95.

Slavkin HC. Maturity and oral health: live longer and better. J Am Dent Assoc 2000;131(6):805-8.

Smith DJ, Ebersole JL, Taubman MA. Local and systemic immune response in aged hamsters. Immunology 1983;50(3):407-13. 
Smith DJ, Taubman MA, Ebersole JL. Ontogeny ans Senescence of salivary immunity. J Dent Res 1987;66(2):451-6.

Smith DJ, Joshipura K, Kent R, Taubman MA. Effect of age on immunoglobulin content and volume of human labial gland saliva. J Dent Res 1992;71(12);1891-4.

Souza CP, Tamaki R. Implicações do uso de prótese total na geriatria. ROBRAC 1996;6(19):29-31.

Souza-Leão SMB. Sistema imune: biomarcador de senescência. Rio de Janeiro; 1999. [Monografia do Curso de Especialização em Envelhecimento e Saúde do IdosoEscola Nacional de Saúde Pública da Fundação Oswaldo Cruz].

Storch B, Bellagamba HP. A terceira idade na odontologia. RGO 1982;30(4):311-5.

Streckfus CF, Bigler LR. Saliva as a diagnostic fluid. Oral dis 2002;8(2):69-76.

Streckfus CF, Welsh S, Brown RH, Marcus S, Cherry-Peppers G. Parotid function and composition of parotid saliva among elderly edentulous African-American diabetics. J Oral Pathol Med 1994;23(6):277-9.

Streckfus CF, Welsh S, Strahl RC. Diminution of parotid IgA secretion in an elderly black population taking antihypertension medications. Oral Surg Oral Med Oral Pathol $1991 ; 71(1): 50-4$.

Su J, Lustbader E, Solomowitz BH, Dowrich IA. Geriatric dentistry. NY Dental J 2002;68(3):25-9.

Tappuni AR, C hallacombe SJ. A comparison of salivary immunoglobulin A ( $\lg A)$ and $\lg A$ subclass concentrations in predentate and dentate children and adults. Oral Microbiol Immunol 1994;9(3):141-5.

Tenovuo J. Oral defense factors in the elderly. Endod Dent Traumatol 1992;8(3):93-8.

Tenovuo J. Antimicrobial agents in saliva protection for the whole body. J Dent Res 2002;81(12):807-9. 
Tlaskalová-Hogenová H, Tucková L, Lodinavá-Zadniková R, Stepanková R, Cukrowska $B$, Funda DP et al. Mucosal immunity: Its role in defense and allergy. Int Arch Allergy Immunol 2002;128(2):77-89.

Toniolo Neto J. Nunca é cedo demais. Rev Veja 1999;32(48);126-7.

Vaz N, Faria AMC, Verdolin BA, Carvalho CR. Immaturity, ageing and oral tolerance Scand J Immunol 1997;46:225-9.

Verthelyi D. Sex hormones as immunomodulators in health and disease. Int. Immunopharmacol 2001;(1):983-93.

Viselli SM, Stanziale S, Shults K, Kovacs WJ, Olsen NJ. Castration alters peripheral immune function in normal male mice Immunology1995;(84):337-42.

Weksler ME. Immune senescence: Deficiency or dysregulation. Nutr Rev 1995;53(4):S37.

Werner CW, Saunders MJ, Paunovuch E, Yeh C. Odontologia geriátrica. Rev Fac Odontol Lins 1998;11(1):62-70.

Yung RL. Changes in immune function with age. Rheum Dis Clin North Am 2000;26(3):455-73 
ANEXO B - Ficha de Identificação do Paciente, Anamnese e Exame Clínico

FICHA DE IDENTIFICAÇÃO DO PACIENTE NÚMERO

NOME DATA DO EXAME

DATA NASC IDADE SEXO COR

ENDEREÇO TELEFONE

BAIRRO CEP CIDADE

\section{ANAMNESE}

ESTADO DE SAÚDE ATUAL

ESTÁ EM TRATAMENTO MÉDICO? POR QUÊ?

MEDICAMENTOS UTILIZADOS NOS ÚLTIMOS TRÊS MESES MEDICAMENTOS DE USO CONTÍNUO TEMPO DE USO DA(S) PRÓTESE(S) QUANDO FOI REALIZADA A ÚLTIMA EXTRAÇAO?

\section{EXAME CLÍNICO}

ELEMENTOS DENTAIS AUSENTES

ELEMENTOS DENTAIS PRESENTES

HÁ PRESENÇA DE ALTERAÇÃO GENGIVAL?

EM QUAL(IS) DENTE(S)? 
Anexo C - Termo de Consentimento Informado

UNIVERSIDADE DE SÃO PAULO

FACULDADE DE ODONTOLOGIA

DEPARTAMENTO DE PRÓTESE DENTÁRIA

Projeto de Mestrado

\section{"Análise da Influência do envelhecimento e da perda dos elementos dentais nos níveis totais de imunoglobulina do tipo A na saliva"}

\section{TERMO DE CONSENTIMENTO INFORMADO}

Você está sendo convidado a participar desta pesquisa que vai avaliar a influência do envelhecimento e da perda dos dentes nos níveis de imunoglobulina do tipo A secretória na saliva. Esta imunoglobulina é uma substância que apresentamos na saliva que quando medida nos fornece conhecimentos sobre o estado do sistema imunológico de mucosas, ou seja, sobre o estado da defesa do organismo diante das doenças.

Este estudo é conduzido pela aluna do Programa de Pós Graduação em Prótese Dentária da Faculdade de Odontologia da Universidade de São Paulo ANA PATRICIA CARNEIRO GONÇALVES BEZERRA COELHO, sendo orientada pela Profa. Dra. DALVA CRUZ LAGANÁ.

Se você concordar em participar da pesquisa, será necessária a doação de uma amostra de saliva que será colhida em um frasco plástico esterilizado. Esta doação será feita através do ato de cuspir diretamente no frasco fornecido pelo pesquisador.

A pesquisa não oferece riscos e os benefícios de participar serão em prol da evolução dos estudos a cerca da influência do processo de envelhecimento no organismo humano e o desconto de $50 \%$ do valor total do tratamento protéico.

Tanto seu nome quanto seus registros serão confidenciais, apenas a amostra de saliva será utilizada nesta pesquisa. Sua decisão de participar ou não da pesquisa não afetará seu atendimento, podendo também desistir a qualquer momento.

Eu li todas as informações. Todas as dúvidas foram esclarecidas. Forneço meu consentimento para participar da pesquisa proposta.

NOME:

IDADE:

ASSINATURA:

ASSINATURA DO PESQUISADOR:

DATA: 
ANEXO A - Parecer do Comitê de Ética

\author{
Faculdade de Odontologia \\ Universidade de Sảo Paulo
}

\title{
PARECER $n^{\circ} 181 / 03$
}

Protocolo 171/03

Com base em parecer do retator o Comité de Ética em Pesquisa, APROVOU o protocolo de pesquisa 'Análise da influência do envelhecimento e da perda dos elementos dentais nos niveis totais de imunoglobulina do tipo $A$ na saliva", de responsabilidade da pesquisadora Ana Patricia Carneiro Gonçalves Bezerra Coelho, sob orientaçăo da Prof" Dr" Maria Cecilia Miluzzi Yamada.

Tendo em vista a legislaçăo vigente, devem ser encaminhados a este Comitê relatórios anuais (parciais ou finais, em funçăo da đuração da pesquisa) referentes ao andamento da pesquisa e ao término cópia do trabalho em "cd". Qualquer emenda do projeto original deve ser apresentada a este CEP para apreciaçăo, de forma clara e sucinta, identificando a parte do protocolo a ser modificada e suas justificativas.

São Paulo, 30 de outubro de 2003.

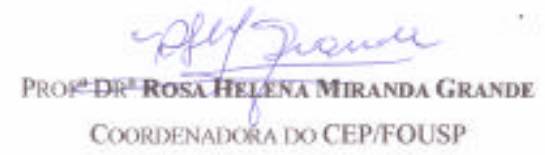

Av. Prot. Lineu Prestes, 2227 - Cidade Universataria "Armando de Salles Oaiveira" CEP 0 $5508-900$ Săo Paulo - SP Diretoria Telefax (011) $38140062-30917817 / 60$ 